\title{
Interleukin-6 Upregulates Neuronal Adenosine A, Receptors: Implications for Neuromodulation and Neuroprotection
}

\author{
Knut Biber", 1,6, A Pinto-Duarte ${ }^{2,3,6}$, MC Wittendorp', AM Dolga ${ }^{4}$, CC Fernandes ${ }^{2,3}$, \\ J Von Frijtag Drabbe Künzel ${ }^{5}$, JN Keijser ${ }^{4}$, R de Vries', AP ljzerman ${ }^{5}$, JA Ribeiro ${ }^{2,3}$, U Eisel ${ }^{4}$, \\ AM Sebastião ${ }^{2,3}$ and HWGM Boddeke' \\ 'Department of Medical Physiology, University Medical Center Groningen, University of Groningen, Groningen, The Netherlands; ${ }^{2}$ Institute of \\ Pharmacology and Neurosciences, Faculty of Medicine, University of Lisbon, Lisbon, Portugal; ${ }^{3}$ Institute of Molecular Medicine, University of \\ Lisbon, Lisbon, Portugal; ${ }^{4}$ Department of Molecular Neurobiology, University of Groningen, Groningen, The Netherlands; ${ }^{5}$ Leiden/Amsterdam \\ Center for Drug Research, Gorlaeus Laboratories, Leiden, The Netherlands
}

\begin{abstract}
The immunological response in the brain is crucial to overcome neuropathological events. Some inflammatory mediators, such as the immunoregulatory cytokine interleukin-6 (IL-6) affect neuromodulation and may also play protective roles against various noxious conditions. However, the fundamental mechanisms underlying the long-term effects of IL-6 in the brain remain unclear. We now report that IL-6 increases the expression and function of the neuronal adenosine $A_{1}$ receptor, with relevant consequences to synaptic transmission and neuroprotection. IL-6-induced amplification of $A_{1}$ receptor function enhances the responses to readily released adenosine during hypoxia, enables neuronal rescue from glutamate-induced death, and protects animals from chemically induced convulsing seizures. Taken together, these results suggest that IL-6 minimizes the consequences of excitotoxic episodes on brain function through the enhancement of endogenous adenosinergic signaling.

Neuropsychopharmacology (2008) 33, 2237-2250; doi:I 0. I038/sj.npp. I 301612; published online 7 November 2007
\end{abstract}

Keywords: brain inflammation; cytokines; excitotoxicity; seizures; hypoxia; adenosine $A_{1}$ receptor

\section{INTRODUCTION}

In the past years important functions were ascribed to cytokines within the central nervous system. Despite the constitutive expression of these mediators in the brain is usually low, their secretion increases dramatically in response to specific stimuli, such as infection or injury. Due to numerous reports showing the augmented expression of the immunoregulatory cytokine interleukin-6 (IL-6) in a variety of neurodegenerative diseases, this molecule is now recognized as a key player in brain pathology (Gadient and Otten, 1997, Gruol and Nelson, 1997). However, the role of IL-6 in that phenomenon has been regarded as a doubleedged sword, since both neuroprotective and detrimental properties were associated to its expression. On one hand it has been shown that IL-6 protects cultured neurons (Carlson et al, 1999; Ali et al, 2000; Pizzi et al, 2004) and is beneficial in several models of neurodegenerative diseases

\footnotetext{
*Correspondence: Dr K Biber, Department of Medical Physiology, University Medical Center Groningen, University of Groningen, Ant. Deusinglaan I, Groningen 9713 AV, The Netherlands, Tel: + 3150 3632706, Fax: + 3150363275 I, E-mail: k.p.h.biber@med.umcg.nl

${ }^{6}$ These authors contributed equally to this study.

Received I8 December 2006; revised I 8 September 2007; accepted 29 September 2007
}

(Bensadoun et al, 2001; Bolin et al, 2002; Penkowa et al, 2001; Loddick et al, 1998; Ali et al, 2000, Swartz et al, 2001; Herrmann et al, 2003); on the other hand, chronic treatment of cultured neurons with IL-6 or chronic expression of IL-6 in astrocytes might result in neuronal death and neurodegeneration (Qiu et al, 1998; Nelson et al, 2004; Conroy et al, 2004; Campbell et al, 1993).

Despite the large body of data on the effects of IL- 6 in brain, the molecular events that lead either to IL-6dependent protection or death of neurons remain unclear. We have previously shown that IL-6 induces the upregulation of mRNA transcripts for the adenosine $A_{1}$ receptor in the brain (Biber et al, 2001). Functional adenosine $A_{1}$ receptors fulfill important neuroprotective properties during excitotoxic conditions, causing the inhibition of glutamate release from the presynaptic terminal (Barrie and Nicholls, 1993), the downregulation of postsynaptic NMDA receptor-mediated currents (de Mendonça et al, 1995; Sebastião et al, 2001) and the stabilization of the postsynaptic cell membrane (Trussell and Jackson, 1985; Gerber and Gahwiler, 1994). Despite the fact that adenosine $\mathrm{A}_{1}$ receptor has been recurrently discussed as a potential target for the treatment of neurodegenerative diseases (Ribeiro, 2005), adenosine $A_{1}$ receptor agonists are not used with therapeutic purposes, mostly due to prominent 
peripheral side effects, short half-lives, and/or receptor desensitization (Yan et al, 2003; Stone, 2002; Dalpiaz and Manfredini, 2002). Interestingly, it has been suggested that the enhancement of adenosine $A_{1}$ receptor expression might efficiently induce adenosine $A_{1}$ receptor-mediated neuroprotection (Rudolphi and Schubert, 1996).

Thus, we now investigated if IL- 6 influences the expression and function of neuronal adenosine $A_{1}$ receptors in vitro and in vivo. Looking at three different pathological conditions in which adenosine has proven to be implicated as a protective agent-hypoxia, glutamate-induced cell death, and seizures - we evaluated if the beneficial properties attributed to IL- 6 could be due, at least in part, to the amplification of adenosine $A_{1}$ receptor-mediated actions.

The results reported here underscore the crucial role played by IL- 6 in the regulation of neuronal adenosine $A_{1}$ receptors and demonstrate that such mechanism is involved in the enhancement of $A_{1}$ receptor-mediated signaling in the brain under excitotoxic situations, with a beneficial impact on neuronal survival.

\section{MATERIALS AND METHODS}

\section{Chemicals}

Amphotericin B, pentylenetetrazole (PTZ), poly-L-lysine, RNAse-free DNAse and adenosine deaminase, $( \pm)$ - $\alpha$-amino3-hydroxy-5-methylisoxazole-4-propionic acid hydrate (AMPA) were obtained from Sigma-Aldrich (Zwijndrecht, The Netherlands and Sintra, Portugal). Neurobasal medium, B27 supplement and gentamycin were from Gibco (Breda, The Netherlands). Recombinant IL-6 with a specific activity of $>5 \times 10^{7} \mathrm{U} / \mathrm{mg}$ was purchased from R\&D systems (London, UK) or PeproTech EC Ltd (London, UK). In most experiments $10 \mathrm{U} / \mathrm{ml}$ IL-6 have been used which is comparable to $<200 \mathrm{pg} / \mathrm{ml}$. 1,3-Dipropyl-8-cyclopentylxanthine (DPCPX), $N^{6}$-cyclopentyladenosine (CPA), 6-cyano-2,3-dihydroxy-7nitro-quinoxaline (CNQX), DL-2-amino-5-phosphonovaleric acid (APV), bicuculline methochloride and cycloheximide (CHX), and tetrodotoxin citrate (TTX) were from Tocris Cookson Ltd (Bristol, UK). $N^{6}$-cyclohexyladenosine $\left(\left[{ }^{3} \mathrm{H}\right]-\mathrm{CHA}\right.$ was purchased from Moravek Biochemicals (Brea, CA, USA). iQ SYBR Green supermix at Bio-Rad (Veenendaal, The Netherlands). Rabbit polyclonal antibodies for the adenosine $A_{1}$ receptor were from Abcam (Cambridge, UK) or Affinity Bioreagents (Golden, CO, USA); monoclonal and polyclonal antibodies for $\beta$-actin were purchased from MP Biomedicals (Amsterdam, The Netherlands) and Abcam, respectively.

\section{Animals}

All experiments were performed with 3-month-old (except for neuronal cultures, see below) male mice (C57Bl6 and IL-6-deficient mice on C57Bl6 background; Jackson Laboratory, Bar Harbor, USA). The animals were handled according to European Community guidelines and in accordance with the regulations of the committee for use of experimental animals of the universities of Groningen and Lisbon. The animals were housed in groups of maximum five per cage in a room with controlled light/ dark $(12 / 12 \mathrm{~h})$ cycle and temperature $\left(21^{\circ} \mathrm{C}\right)$. Food and water were supplied ad libidum. Mice were anesthetized with halothane before decapitation.

\section{Electrophysiological Recordings in Hippocampal Slice Preparations}

Slice preparation was carried out as previously described (Diógenes et al, 2004). Field excitatory postsynaptic potentials (fEPSPs) and whole-cell postsynaptic currents were recorded from the CA1 area of hippocampal slices $(300-400 \mu \mathrm{m})$ upon stimulation of the Schaffer collateral fibers (rectangular pulses of 0.1-0.2 ms duration delivered each $15 \mathrm{~s}$ ). Drugs were applied to the perfusion solution ( $3 \mathrm{ml} / \mathrm{min})$, which contained $\mathrm{NaCl} 125 \mathrm{mM}, \mathrm{KCl} 3 \mathrm{mM}$, $\mathrm{NaH}_{2} \mathrm{PO}_{4} 1.25 \mathrm{mM}, \mathrm{NaHCO}_{3} 25 \mathrm{mM}, \mathrm{CaCl}_{2} 2 \mathrm{mM}, \mathrm{MgSO}_{4}$ $1 \mathrm{mM}$, and glucose $10 \mathrm{mM}$. Bath temperature was $32^{\circ} \mathrm{C}$ throughout fEPSPs recording experiments. To elicit pairedpulse facilitation (PPF; see eg Citri and Malenka, 2007), the Schaffer collaterals were stimulated twice with $50 \mathrm{~ms}$ interpulse interval. Synaptic facilitation was quantified as the ratio between the slopes of the fEPSP elicited by the second and the first stimuli. While evaluating the influence of a drug (CPA) on PPF, the difference in PPF values obtained in the presence and in the absence of that drug in the same slice $(\triangle \mathrm{PPF})$ was calculated. Hypoxia was induced substituting the artificial cerebrospinal fluid (aCSF) by an identical aCSF preequilibrated with 95\% $\mathrm{N}_{2} / 5 \% \quad \mathrm{CO}_{2}$ for $3 \mathrm{~min}$. This manipulation reduces bath oxygen tension in the recording chamber from $\approx 600$ to $\approx 250 \mathrm{~mm} \mathrm{Hg}$ (Sebastião et al, 2000). Each slice was subjected to a single period of hypoxia, since the effects of hypoxia may be modified by subsequent episodes in the same slice (Schurr et al, 1986). To minimize individual variation between slices, the effects of hypoxia were compared in control and in test slices with less than $1 \mathrm{~h}$ of interval.

Patch clamp experiments were performed at room temperature $\left(22-25^{\circ} \mathrm{C}\right)$ in $\mathrm{CA} 1$ pyramidal cells identified under infrared visualization and electrophysiologically characterized (Staff et al, 2000). Patch electrodes (5-7 M $\Omega$ ) were filled with $125 \mathrm{mM}$ potassium gluconate, $11 \mathrm{mM} \mathrm{KCl}$, $0.1 \mathrm{mM} \mathrm{CaCl}_{2}, 2 \mathrm{mM} \mathrm{MgCl}_{2}, 1 \mathrm{mM}$ EGTA, $10 \mathrm{mM} \mathrm{HEPES}$, $2 \mathrm{mM}$ NaATP, $0.3 \mathrm{mM}$ NaGTP, and $10 \mathrm{mM}$ TRIS phosphocreatine; pH 7.3 adjusted with $\mathrm{KOH}, 280-290$ mOsm. Every cell was recorded from a separate slice. Resting membrane potentials were between -60 and $-70 \mathrm{mV}$. Junction potentials were not corrected. Whole-cell postsynaptic currents were recorded in voltage-clamp mode $\left(V_{\mathrm{h}}=-70 \mathrm{mV}\right)$. Averages of four consecutive excitatory postsynaptic potentials (EPSCs) or inhibitory postsynaptic currents (IPSCs) were continuously acquired. IPSCs were obtained in the presence of CNQX $(20 \mu \mathrm{M})$ and APV $(10 \mu \mathrm{M})$ and were completely blocked after superfusion of bicuculline $(20 \mu \mathrm{M})$. AMPA receptor-mediated postsynaptic currents were evoked by pressure ejection of AMPA $(20 \mu \mathrm{M})$ to the dendrites in the presence of TTX $(1 \mu \mathrm{M})$. Data were digitally acquired in voltage-clamp mode using an EPC-7 amplifier (List Biologic, Campbell, CA), Digidata 1322A A-D converter and LTP program or Win LTP (Anderson and Collingridge, 2001, 2007). A small voltage step $(5 \mathrm{mV}$, $50 \mathrm{~ms}$ ) was delivered before evoking each postsynaptic current to monitor membrane and series resistances; if one 
of both or holding current changed significantly, the experiment was rejected.

\section{Preparation of Hippocampal Synaptosomes}

Hippocampal slices kept in the absence or in the presence of exogenously added IL- 6 for $6 \mathrm{~h}$ were collected into a sucrose solution ( $320 \mathrm{mM}$ sucrose, $1 \mathrm{mM}$ EDTA, $5 \mathrm{mM}$ HEPES, and $1 \mathrm{mg} / \mathrm{ml} \mathrm{BSA}, \mathrm{pH}$ 7.4) and homogenized by four up-anddown strokes. The homogenate was then centrifuged at $3000 \mathrm{~g}$ for $10 \mathrm{~min}\left(\right.$ at $4^{\circ} \mathrm{C}$ ), the supernatant was collected and centrifuged again at $14000 \mathrm{~g}$ for $12 \mathrm{~min}\left(\right.$ at $4^{\circ} \mathrm{C}$ ) to prepare the synaptosomal P2 fraction, as described previously (Pinto-Duarte et al, 2005).

\section{Primary Neuronal Cultures}

Cortical neurons were prepared from embryonic mouse brains (E15-16) as described before (de Jong et al, 2005). Neurons were used after 6 days in culture. Cells were incubated for 6 or $24 \mathrm{~h}$ with $10 \mathrm{U} / \mathrm{ml} \mathrm{IL}-6$ and then either stimulated for $1 \mathrm{~h}$ with glutamate at various concentrations or incubated for $15 \mathrm{~min}$ with CPA $(1-100 \mathrm{nM})$ or $100 \mathrm{nM}$ DPCPX followed by glutamate challenge for $1 \mathrm{~h}$. The effect of test drugs (IL-6, CPA, or DPCPX) on glutamate-induced neurotoxicity was always evaluated comparing the effect of glutamate in the absence and presence of the test drug in the same batch of neurons.

\section{Determination of Neuronal Viability}

Neuronal viability was determined by the colorimetric MTT (3-(4,5-dimethylthiazol-2-yl-)2,5-diphenyltetrazolium bromide) assay as described previously (Marchetti et al, 2004).

\section{Seizure Induction by Pentylenetetrazole Treatment}

Male wild-type (WT) C57Bl6 and IL-6 knockout mice weighing 23-29g were used. Mice received once daily, for 2 consecutive days, one intraperitoneal injection with $55 \mathrm{mg} /$ $\mathrm{kg}$ PTZ dissolved in $0.9 \%$ saline. Control animals received saline only. Latency of seizure onset was timed and animals were subsequently observed for $1 \mathrm{~h}$. Animals were assigned a seizure score according to the following criteria (Kondziella et al, 2002): $0=$ normal behavior, $1=$ myoclonic jerks, $2=$ minimal seizures without Straub-tail, $3=$ minimal seizures with Straub-tail, $4=$ generalized tonic-clonic seizures, $5=$ like 4 with loss of consciousness and postictal phase, $6=$ like 5 with rotation on their axis, and $7=$ like 6 and death. All PTZ-treated animals showed at least score 2 (minimal seizures) within 5 min. Mice were killed $26 \mathrm{~h}$ after the second injection.

\section{Brain Tissue Preparation from PTZ-Injected Mice}

Brains were removed, the two hemispheres were separated, and subsequently frozen and stored at $-80^{\circ} \mathrm{C}$ until use. Both groups that received PTZ injections (WT and IL-6 knockout) were further divided according to the severity of the seizures. The 'PTZ-high' groups consisted of animals that showed tonic-clonic seizures (score 4) after at least one of the two PTZ injections. All other animals that received PTZ injections were assigned to the 'PTZ-low' groups. WT and IL-6 knockout control groups contained 15 animals, while the four PTZ-treated groups (PTZ-high and PTZ-low) consisted of 6-8 animals per group.

The right hemispheres were prepared for RNA analysis (see below) and radioligand binding studies (Lohse et al, 1984), while the left hemispheres were used for autoradiography.

\section{RNA Isolation and Reverse Transcription-Polymerase Chain Reaction}

Tissue was lysed in guanidinium isothiocyanate/mercaptoethanol buffer and total RNA was extracted with one phenol/chloroform step (Chomczynski and Sacchi, 1987) and transcribed into cDNA as described (Biber et al, 2001).

\section{Real-Time Polymerase Chain Reaction}

Adenosine $A_{1}$ receptor mRNA expression in the brains of WT and IL-6 knockout mice was analyzed by real-time PCR using the iCycler (Bio-Rad) and the iQ SYBR Green supermix. Mouse ribosomal protein L32-3A (rpL32A) primers and hypoxanthine guanine phosphoribosyl transferase (HPRT1) primers were used for normalization to housekeeping genes. These genes did not show variations in response to the experimental treatment (see Table 1 for primer sequences). The comparative $C_{\mathrm{t}}$ method (amount of target amplicon $\mathrm{X}$ in sample $\mathrm{S}$, normalized to a reference $R$ and related to a control sample $\mathrm{C}$, calculated by 2- $\left(\left(C_{\mathrm{t}} \mathrm{X}, \mathrm{S}-C_{\mathrm{t}} \mathrm{R}, \mathrm{S}\right)-\left(C_{\mathrm{t}} \mathrm{X}, \mathrm{C}-C_{\mathrm{t}} \mathrm{R}, \mathrm{C}\right)\right)$ was used to determine the relative expression levels (Livak and Schmittgen, 2001).

\section{Western Blotting}

Primary cortical neurons $\left(2 \times 10^{6}\right.$ cells per well $)$ were washed twice with ice-cold phosphate-buffered saline, subsequently lysed by the addition of $0.15 \mathrm{ml}$ of lysis buffer (20 mM Tris, $150 \mathrm{mM} \mathrm{NaCl}, 1 \mathrm{mM}$ EDTA, $1 \mathrm{mM}$ EGTA, $1 \%$ Triton, $2.5 \mathrm{mM}$ sodium pyrophosphate, and $1 \mathrm{mM}$ sodium orthovanadate and protease inhibitors). The homogenates were centrifuged for $10 \mathrm{~min}$ at 12000 r.p.m. and the supernatants were collected. P2 synaptosomal fraction was

Table I Sequence of the Primers Used for Real-Time PCR

\begin{tabular}{|c|c|c|c|}
\hline Gene & Accession number & Forward primer $\left(5^{\prime}-3^{\prime}\right)$ & Backward primer $\left(5^{\prime}-3^{\prime}\right)$ \\
\hline rpL32A & X06483 & GCTGGAGGTGCTGCTGATGT & ACTCTGATGGCCAGCTGTGC \\
\hline HPRTI & $\times 62085$ & GACTTGCTCGAGATGTCA & TGTAATCCAGCAGGTCAG \\
\hline Ado $A_{1} R$ & AJ555877 & ССTCTCCGGTACAAGACAGT & GGTGTCAGGCCTACCACAAG \\
\hline
\end{tabular}


lysed in RIPA buffer $(50 \mathrm{mM}$ Tris, $150 \mathrm{mM} \mathrm{NaCl}, 1 \mathrm{mM}$ EDTA, 1\% NP-40, $0.1 \%$ SDS, $1 \mathrm{mM}$ sodium orthovanadate and protease and phosphatase inhibitors, adjusted to $\mathrm{pH}=8$ ). Samples were boiled for $5 \mathrm{~min}$ in Laemmli's buffer ( $2 \%$ SDS, $5 \%$ DTT). A total of 20 íg protein in each sample was separated by $10-12 \%$ SDS-PAGE and transferred to Immobilon $\mathrm{P}$ polyvinylidene difluoride membranes (Millipore Corporation). After blocking for $1 \mathrm{~h}$ in TBS with $0.1 \%$ Tween 20 with $5 \%$ low-fat milk, membranes were incubated overnight at $4{ }^{\circ} \mathrm{C}$ with a rabbit anti-adenosine $\mathrm{A}_{1} \mathrm{R}$ antibody ( $1: 1000$, Affinity Bioreagents or $1: 1000$, Abcam) and then with a secondary antibody conjugated with horseradish peroxidase or with an alkaline phosphatase labeled secondary antibody for $1 \mathrm{~h}$ at room temperature. Afterwards it was processed for protein detection using Super SignalTM substrate (Pierce) or using the ECL detection system (Tropix) according to the manufacturer's instructions. $\beta$ Actin ( $1: 10000$, Abcam or $1: 10000$, MP Biomedicals) was used as a loading control. We recently cloned and expressed mouse adenosine $\mathrm{A}_{1}$ receptor in $\mathrm{CHO}$ cells (Wittendorp et al, 2004). Accordingly, $\mathrm{CHO}$ cells expressing mouse adenosine $A_{1}$ receptor have been used as a positive control in western blotting experiments showing that the used antibody recognized a band of $37 \mathrm{kDa}$ only in cells that stably expressed mouse adenosine $A_{1}$ receptors (data not shown).

\section{Radioligand Binding Assay}

For the determination of the maximum bound radioligand, membranes were incubated for $1 \mathrm{~h}$ at $25^{\circ} \mathrm{C}$ in $50 \mathrm{mM}$ Tris/ $\mathrm{HCl}\left(\mathrm{pH} 7.4\right.$ at $\left.25^{\circ} \mathrm{C}\right)$ in the presence of $4 \mathrm{nM}\left[{ }^{3} \mathrm{H}\right]-\mathrm{DPCPX}$ $\left(K_{\mathrm{i}}=1.4 \mathrm{nM}\right)$; at this concentration one can assume that all adenosine $A_{1}$ receptors present in the preparation will be occupied, making the amount of $\left[{ }^{3} \mathrm{H}\right]-\mathrm{DPCPX}$ binding informative on the number of adenosine $A_{1}$ receptors. Each experiment was performed in triplicate. Nonspecific binding was determined in the presence of $100 \mu \mathrm{M} \mathrm{CPA}$. Incubations were stopped with $1 \mathrm{ml}$ ice-cold buffer and bound radioligand was subsequently recovered by filtration through Whatman GF/B filters. Filters were washed three times and retained radioactivity was measured by liquid scintillation counting (LKB Wallac, 1219 Rackbeta).

\section{Autoradiography}

Sections were preincubated in Tris- $\mathrm{HCl}$ buffer, $170 \mathrm{mM}, \mathrm{pH}$ 7.4 containing $0.5 \mathrm{U} / \mathrm{ml}$ adenosine deaminase for $3 \times 10 \mathrm{~min}$ at room temperature, washed out, and dried in a stream of cold air. For the labeling of adenosine $A_{1}$ receptors, sections were incubated with $3.0 \mathrm{nM}\left[{ }^{3} \mathrm{H}\right] \mathrm{N} 6$-cyclohexyladenosine $\left(\left[{ }^{3} \mathrm{H}\right]-\mathrm{CHA}\right.$, specific activity $\left.20 \mathrm{Ci} / \mathrm{mmol}\right)$ in $170 \mathrm{mM}$ Tris$\mathrm{HCl}$ buffer including $0.5 \mathrm{IU} / \mathrm{ml}$ adenosine deaminase at room temperature for $90 \mathrm{~min}$. To determine nonspecific binding, sections were incubated in the presence of $3 \mu \mathrm{M}$ CPA. Following incubation, unbound radioactivity was removed by rinsing the sections three times for $2 \mathrm{~min}$ in ice-cold Tris- $\mathrm{HCl}$ buffer, $50 \mathrm{mM}$ ( $\mathrm{pH} 7.4$ ), and rinsing once for $5 \mathrm{~s}$ in ice-cold distilled water to remove buffer salts. The sections were then dried in a stream of cold air. Dried sections were exposed to Numico hyperfilm, stored in an $\mathrm{X}$-ray film cassette for 4 month at $-80^{\circ} \mathrm{C}$ and subsequently developed. Quantification analysis of the resulting autoradiographic images was performed using an automatic image analysis system (Quantimet 500, Leica, Cambridge). Optical density was measured in hippocampus and cortex in six sections per mouse. The values of the sections were averaged for each mouse. Optical density measurements from each brain area were converted into nCi per mg tissue, according to the calibration curve obtained from the tritium standards. Results are given as mean $\pm \operatorname{SEM}(n=6)$.

\section{Data Analysis}

Data are presented as mean \pm SEM from $n$ experiments. When comparing two groups of results, statistical significance was assessed using Student's $t$-test. When doing multiple comparisons, statistical significance was assessed by one-way ANOVA followed by the Bonferroni correction. Values of $\mathrm{P}<0.05$ were considered statistically significant.

\section{RESULTS}

\section{Influence of IL-6 on Adenosine $A_{1}$ Receptor-Mediated Actions on Synaptic Transmission}

IL-6 enhances the expression and the inhibitory actions of presynaptic adenosine $A_{1}$ receptors on glutamatergic transmission. Adenosine $\mathrm{A}_{1}$ receptor activation is well known to decrease synaptic transmission in the hippocampus (Sebastião et al, 1990). Therefore, electrophysiological experiments were carried out to investigate if a sustained elevation of IL- 6 levels in the hippocampus modified the neuromodulatory actions of adenosine $A_{1}$ receptors. In the first series of experiments we performed cumulative concentration-response curves for the inhibitory effects of the $A_{1}$ selective agonist, CPA $(1.5-50 \mathrm{nM})$, on the slope of fEPSPs recorded from control slices and slices exposed to IL-6 $(10 \mathrm{U} / \mathrm{ml})$ for $5-8 \mathrm{~h}$. As Figure 1a shows, treatment with IL-6 induced a shift to the left of the concentrationresponse curves of $\mathrm{CPA}$, without changing its maximal effect. The EC50 of CPA-induced inhibition was $5 \mathrm{nM}(95 \%$ confidence interval $4.8-5.2 \mathrm{nM}, n=3$ ) in the presence of IL-6, significantly different $(p<0.05)$ from the control EC50, which was $7.8 \mathrm{nM}(95 \%$ confidence interval $7.7-7.9 \mathrm{nM}$, $n=5$ ) (Figure $1 \mathrm{a}$ and $\mathrm{b}$ ).

Also when CPA was tested at a single concentration of $5 \mathrm{nM}$, the inhibition of fEPSPs was significantly more pronounced $(p<0.05)(32.2 \pm 3.6 \%, n=5)$ in slices exposed to IL-6 (10 U/ml for 5-8 h), as compared to slices kept in the absence of other pharmacological drugs (18.2 $\pm 1.8 \%$, $n=6)$. To rule out nonspecific effects of IL-6, in a different pool of experiments we compared the effect of $5 \mathrm{nM} \mathrm{CPA}$ in control slices and in slices treated with heat-inactivated IL-6 for 5-8 h (HI-IL-6 consisted of $10 \mathrm{U} / \mathrm{mI}$ IL- 6 boiled for $30 \mathrm{~min}$ ). As expected, the inhibition caused by CPA was not significantly different $(p>0.05)$ in both conditions (control: $23.5 \pm 2.5 \%$; HI-IL-6: $23.8 \pm 1.4 \% ; n=2$ ).

Previous studies have shown that adenosine $A_{1}$ receptor activation enhances PPF, presumably by inhibiting the release of neurotransmitters induced by the first stimulus and consequently increasing the amount of neurotransmitters to be released by the second stimulus. Thus, we performed PPF experiments to investigate if IL-6-induced 


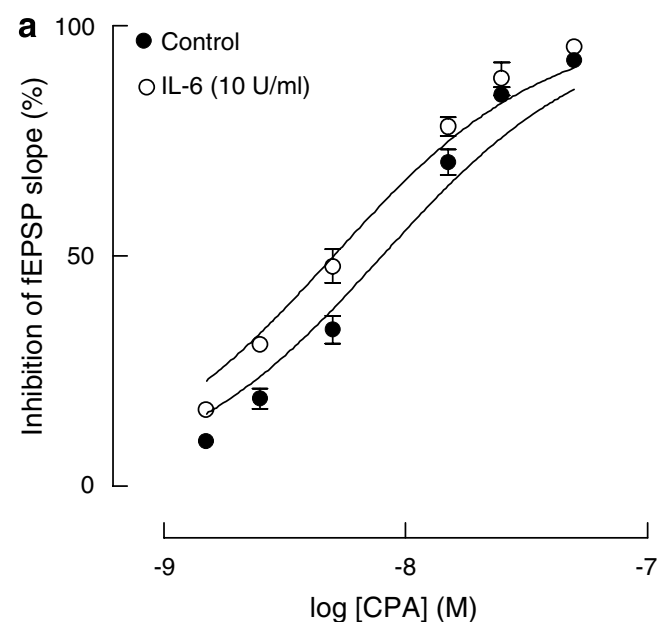

b
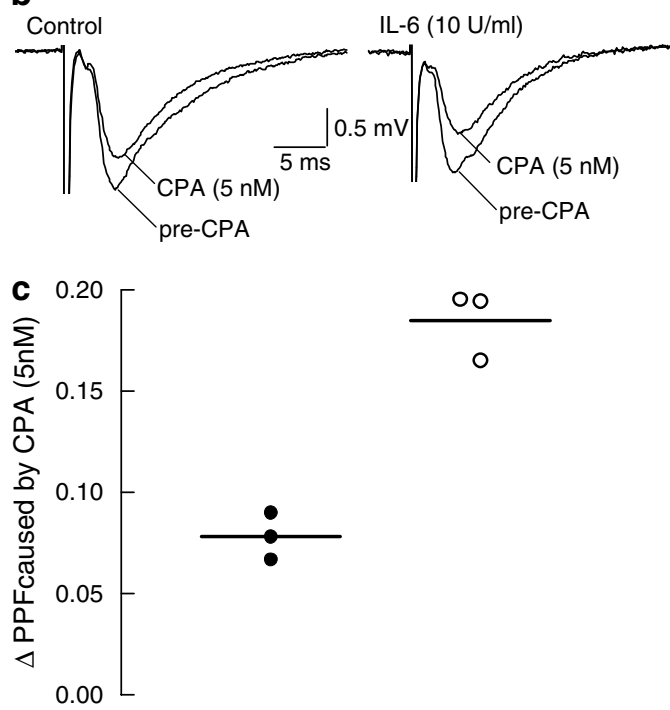

Control

IL-6

Figure I Interleukin-6 (IL-6) potentiates the neuromodulatory actions of presynaptic adenosine $A_{1}$ receptors on hippocampal synaptic transmission. (a) Cumulative concentration-response curves for the effects of the $A_{\text {I }}$ receptor agonist, $N^{6}$-cyclopentyladenosine (CPA, I.5-50 nM), on the slopes of field excitatory postsynaptic potentials (fEPSPS) recorded from the CAI area of hippocampal slices. In the ordinates, $0 \%$ corresponds to fEPSPs slopes before the addition of CPA $(1.30 \pm 0.14 \mathrm{mV} / \mathrm{ms}, n=5$, in control slices, and $1.36 \pm 0.17 \mathrm{mV} / \mathrm{ms}, n=3$, in slices exposed to IL-6 for $5-8 \mathrm{~h}, \mathrm{O}$ ), and $100 \%$ represents a complete inhibition of fEPSPs. (b) Superimposed traces obtained before (pre-CPA) and after the application of CPA in a control slice (left) and in a slice previously exposed to IL-6 for $5 \mathrm{~h}$ (right). Each trace is the average of eight consecutive responses and is composed of the stimulus artifact, presynaptic volley, and fEPSP; the scale applies to panels $(\mathrm{a})+(\mathrm{b})$. (c) Variation $(\Delta)$ of paired-pulse facilitation (PPF) in the absence and presence of CPA in three matched experiments performed in control slices ( ) and in slices from the same hippocampi exposed to $\mathrm{LL}-6$ for 5-8 $\mathrm{h}(\mathrm{O})$. Individual $\triangle \mathrm{PPF}$ values in the threes experiments were 0.07 (control) and 0.17 (IL-6); 0.09 (control) and 0.19 (IL-6); and 0.08 (control) and 0.20 (IL-6).

potentiation of $A_{1}$ receptor neuromodulatory actions occurred at presynaptic sites. In the absence of CPA, PPF corresponded to a ratio of $1.6 \pm 0.08$ in control conditions and $1.7 \pm 0.1$ in IL-6-treated slices ( $n=3$ each). As expected,
CPA ( $5 \mathrm{nM}$ ) increased PPF in both conditions; remarkably, as shown in Figure 1c, CPA-induced enhancement of PPF $\left(\triangle \mathrm{PPF}\right.$, calculated as $\mathrm{PPF}_{\mathrm{CPA}}-\mathrm{PPF}_{\text {pre- } \mathrm{CPA}}$ in the same slice) was always significantly greater $(p<0.05, n=3$ matched experiments) in IL-6-treated slices $(0.19 \pm 0.01)$ than in control slices $(0.08 \pm 0.01)$, supporting a presynaptic locus for IL-6-induced enhancement of adenosine $A_{1}$ receptormediated effects on synaptic transmission.

To investigate if IL-6-induced enhancement of adenosine $A_{1}$ receptor-mediated inhibition of synaptic transmission occurred at the single-neuron level, we performed wholecell voltage-clamp recordings from CA1 pyramidal cells upon stimulation of the Schaffer collateral afferents. To avoid preconditioned responses of $A_{1}$ receptors, the effect of CPA ( $5 \mathrm{nM})$ was investigated in only one neuron per slice, control (absence of exogenous IL-6) and test (incubation with $10 \mathrm{U} / \mathrm{ml} \mathrm{IL-6}$ during 5-8 h) slices being from the same hippocampus. As illustrated in Figure 2 (panels A and B), CPA $(5 \mathrm{nM})$ inhibited EPSCs by $27.5 \pm 1.11 \%(n=5)$ in control conditions. IL- 6 significantly $(p<0.05)$ exacerbated CPA-induced depression of the EPSCs to $52.7 \pm 5.36 \%$ $(n=3$; Figure $2 \mathrm{a}$ and $\mathrm{b})$. Similar effects were found with $100 \mathrm{U} / \mathrm{ml}$ IL-6 (Figure 2b). The incubation with or without IL-6 for up to $8 \mathrm{~h}$ did not change tissue integrity, the morphology of the cells nor the effects of CPA on EPSPs (data not shown). We also looked for a putative role of postsynaptic $A_{1}$ receptors on the modulation of synaptic transmission. Since in our conditions (high $\mathrm{Mg}^{2+}$ and $V_{\mathrm{h}}=-70 \mathrm{mV}$ ) synaptic transmission was mostly mediated by the activation of postsynaptic AMPA receptors, we tested the action of CPA on pharmacologically isolated postsynaptic AMPA receptor-mediated currents. The amplitude of postsynaptic AMPA-induced currents was not affected by CPA $(5 \mathrm{nM})$ in control conditions $(106.0 \pm 7.4 \%$ of control, $n=3)$. When the concentration of CPA was increased to $100 \mathrm{nM}$, AMPA-evoked currents were still not significantly modified $(p>0.05)$, which solely confirmed the limited contribution of postsynaptic adenosine $A_{1}$ receptors to the modulation of synaptic transmission (Arrigoni et al, 2005); it did not preclude, however, that the upregulation of postsynaptic or somatic $A_{1}$ receptors might assume functional relevance in other experimental paradigms, a possibility which we explored and were able to demonstrate further below using a different in vitro model (see data on neuronal cultures).

The next group of experiments aimed to examine the participation of de novo protein synthesis in IL-6-induced enhancement of $A_{1}$ receptor function on hippocampal synaptic transmission. As shown in Figure $2 b$, treatment of hippocampal slices with the protein synthesis inhibitor CHX during the incubation period with IL-6, completely abolished the potentiation of the inhibitory effect of CPA $(5 \mathrm{nM})$ on electrically evoked EPSCs. CHX per se did not significantly modify $5 \mathrm{nM}$ CPA-induced inhibition of EPSCs $(31.7 \pm 1.6 \%, n=3, p>0.05$ as compared to a control inhibition of $27.5 \pm 1.1 \%, n=5$ ). To investigate whether the involvement of newly synthesized proteins was correlated with the upregulation of presynaptic adenosine $A_{1}$ receptors, we performed western blot experiments in synaptic terminals prepared from control hippocampal slices and IL-6-treated slices. As shown in Figure 2c, IL-6 induced a significant $(p<0.05)$ upregulation of $A_{1}$ receptors 


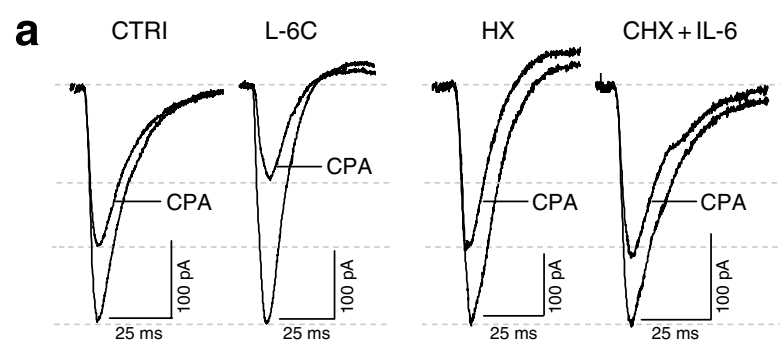

b

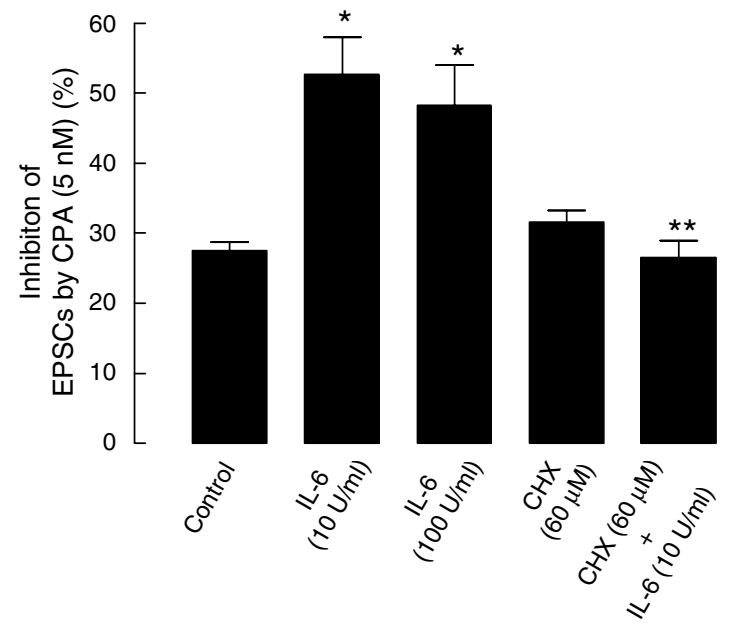

C

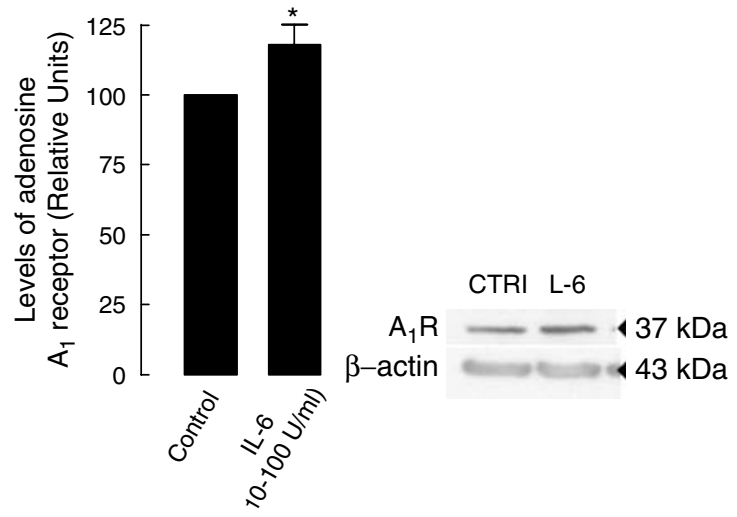

Figure 2 Interleukin-6 (IL-6)-induced enhancement of adenosine $A_{\text {, }}$ receptor function on synaptic transmission requires de novo protein synthesis and is matched by the expression of newly synthesized $A_{\text {, }}$ receptors. (a) Representative excitatory postsynaptic potentials (EPSCs) recorded from pyramidal cells before and during superfusion of $N^{6}$ cyclopentyladenosine (CPA, $5 \mathrm{nM})$ in control (CTR) and IL-6 (I0 U/ml)treated hippocampal slices $(6 \mathrm{~h})$, in the absence or in the presence of the protein synthesis cycloheximide $(\mathrm{CHX})$, as indicated; superimposed recordings were from the same slice. Stimulus artifacts are truncated. (b) Histogram summary percentage decrease in EPSC amplitudes caused by CPA; the slices had been incubated in the absence (control, $n=5$ ) or in the presence of the drugs indicated below each bar $(n=3$ in all cases except for $100 \mathrm{U} / \mathrm{ml} \mathrm{IL-6}$ where $n=2)$; time of incubation with IL-6 and/or CHX: 6-8 h. * $p<0.05$ vs control, ** $p<0.05$ vs IL-6 ( $10 \mathrm{U} / \mathrm{ml})$, one-way ANOVA followed by the Bonferroni correction. Zero percent in the ordinates represents the EPSCs recorded before applying CPA and were $251 \pm 40 p A$ in the absence of any drug, $243 \pm 46 p A$ in slices incubated with IL-6, 24I $\pm 59 \mathrm{pA}$ in slices incubated with $\mathrm{CHX}$, and $240 \pm 35 \mathrm{pA}$ in slices incubated with CHX plus IL-6; 100\% represents a complete inhibition of currents. (c) Western blot analysis of adenosine $A_{1}$ receptor expression in nerve terminals prepared from slices hippocampal slices kept for $6-8 \mathrm{~h}$ in the absence or in the presence of $\mathrm{IL}-6$ ( $10-100 \mathrm{U} / \mathrm{ml})$. Pooled data from four individual experiments and a demonstrative experiment are shown. in this preparation. Taken together, these data suggest that newly synthesized presynaptic $A_{1}$ receptors are involved in the enhancement of $A_{1}$ receptor-mediated effects on synaptic transmission.

While recording EPSCs, GABAergic transmission was not blocked to avoid exacerbated excitability of the slices. The next series of experiments was therefore performed to exclude putative actions of IL-6-induced upregulation of $A_{1}$ receptors on GABAergic transmission. In these trials compound synaptic currents were initially recorded and, after stabilization, the antagonists of AMPA/kainate receptors, CNQX $(20 \mu \mathrm{M})$, and NMDA receptors, APV $(10 \mu \mathrm{M})$, were superfused to isolate the IPSCs. The GABAergic nature of these currents was confirmed at the end of each experiment using the $\mathrm{GABA}_{\mathrm{A}}$ receptor antagonist bicuculline $(20 \mu \mathrm{M})$, which totally blocked the remaining current. In both control and IL-6-stimulated slices, the GABAergic current represented nearly $10 \%$ of the compound current, as assessed by the degree of inhibition by ionotropic glutamate receptor antagonists. Activation of adenosine $\mathrm{A}_{1}$ receptors with CPA $(5 \mathrm{nM})$ did not affect IPSCs $(99.7 \pm 5.9 \%$ of currents amplitude before CPA, $n=3$ ) recorded from control slices, which is in accordance with previous data showing the inability of $A_{1}$ receptors to modulate GABAergic transmission in mature hippocampus (Lambert and Teyler, 1991; Yoon and Rothman, 1991). In slices incubated with IL-6 $(10 \mathrm{U} / \mathrm{ml})$ for $>5-8 \mathrm{~h}, \mathrm{CPA}(5 \mathrm{nM})$ also did not induce significant modifications on IPSCs amplitudes $(95.6 \pm 9.9 \%$ of currents amplitude before CPA, $n=3$, $p>0.05$ ), indicating that IL-6 was unable to unmask a putative $A_{1}$ receptor-mediated action upon GABAergic transmission in the hippocampus.

IL-6 enhances adenosine $A_{1}$ receptor-mediated depression of synaptic transmission during hypoxia. We next investigated the pathophysiological relevance of IL-6-induced enhancement of adenosine $A_{1}$ receptor function on synaptic transmission. The inhibition of synaptic transmission in the hippocampus is crucial to protect neurons from excitotoxicity induced by neuropathological events, such as hypoxia. Under such conditions, considerable amounts of adenosine are released and operate $A_{1}$ receptors to restrain synaptic glutamate release (Sebastião et al, 2001). Thus, we tested the effect of brief ( 3 min) hypoxic episodes in fEPSPs recorded from control and IL-6-treated slices. This manipulation caused little or no appreciable depression of synaptic transmission under control conditions (Figure 3a). However, the same hypoxic insult applied to hippocampal slices previously exposed to IL-6 $(10 \mathrm{U} / \mathrm{ml})$ for $6-8 \mathrm{~h}$, induced a significant $(p<0.05)$ depression of fEPSPs (Figure 3a). This depression was markedly attenuated when DPCPX (100 nM) was present during the incubation period with IL-6 and throughout the experiment $(n=2)$. Yet, the presence of DPCPX during such prolonged period significantly boosted neuronal excitability, increased population spike contamination, and caused abnormal modifications of the recorded fEPSPs, which led us to perform a different pool of experiments in which DPCPX $(100 \mathrm{nM})$ was applied about $30 \mathrm{~min}$ before the hypoxic insult. In these conditions, the depression of fEPSPs recorded from IL-6-treated slices was fully prevented (Figure $3 \mathrm{~b}$ ) and, therefore, can be attributed to the activation of $A_{1}$ receptors by adenosine. In one 

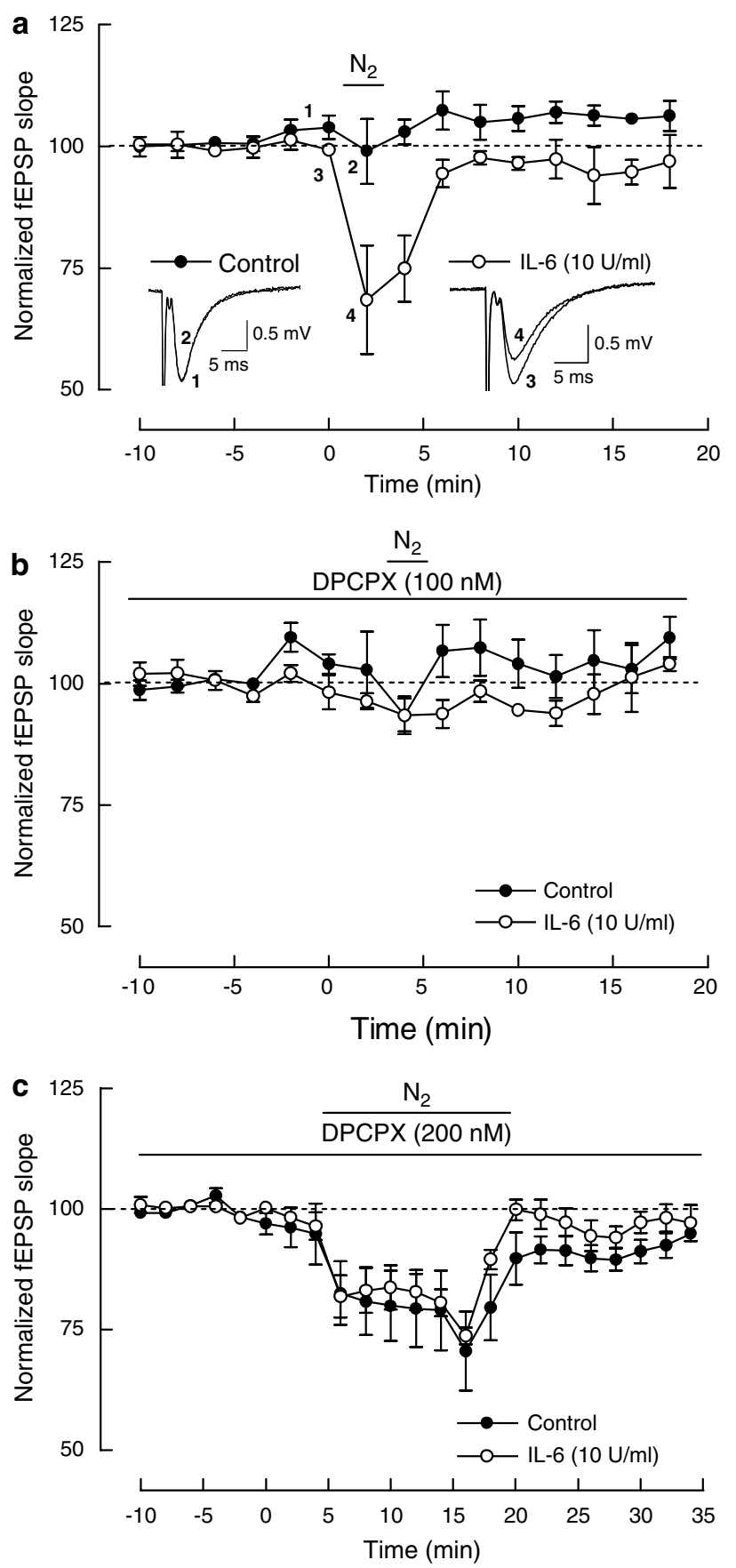

experiment, we induced a longer hypoxic period $(4 \mathrm{~min})$, sufficient to cause a mild depression of synaptic transmission even in control conditions (33.3\%) and the response to hypoxia was still more pronounced $(67.5 \%)$ in a slice taken from the same hippocampus previously exposed to IL-6 $(10 \mathrm{U} / \mathrm{ml})$ for $6 \mathrm{~h}$.

Since prolonged hypoxic periods cause an inhibition of synaptic transmission that results from both adenosine $A_{1}$ receptor-dependent and -independent mechanisms (Lucchi et al, 1996), we further investigated if the later were also influenced by IL-6. As shown in Figure 3c, the depression of synaptic transmission caused by $14 \mathrm{~min}$ of hypoxia in the presence of a supramaximal concentration of the $A_{1}$
Figure 3 Interleukin-6 (IL-6) enhances A, receptor-mediated inhibition of synaptic transmission induced by hypoxia. (a) Time course of the effects of the effect of 3 min hypoxia $\left(\mathrm{N}_{2}\right.$, applied as indicated by the horizontal bar) on field excitatory postsynaptic potentials (fEPSP) slope recorded from control slices (absence of IL-6, $n=3,0$ ) or from slices taken from the same hippocampi but that had been preincubated with $\mathrm{LL}-6(\mathrm{I} 0 \mathrm{U} / \mathrm{ml})$ for $6-8 \mathrm{~h}(n=3,0)$. The inset shows sample traces of fEPSPs recorded before hypoxia ( 1 and 3 ) and after 3 min hypoxia (2 and 4 ) in the absence (left, I and 2) or in the presence of IL-6 (right, 3 and 4); superimposed recordings in each panel were from the same slice, the left and right panel recordings were from different slices from the same hippocampus (see Figure I legend for further details). (b) Effects of a 3 min hypoxic insult induced in the presence of a selective $A_{1}$ receptor antagonist, I,3-Dipropyl-8-cyclopentylxanthine (DPCPX), in control conditions $(n=3, \quad)$ and in slices preincubated with IL-6 for $6-8 \mathrm{~h}(n=4,0)$. (c) Time course of the response to a longer period of hypoxia $(14 \mathrm{~min})$ in the presence of DPCPX, to block $A_{\text {I }}$ receptor actions. In all panels; $100 \%$ in the ordinates corresponds to the averaged fEPSP slope recorded for 10 min before $\mathrm{N}_{2}$; the slope values within the same panel do not differ significantly $(p>0.05)$ between test (slices incubated with IL-6) and control conditions.

receptor antagonist, DPCPX $(200 \mathrm{nM})$, was not modified $(p>0.05)$ by preincubation with IL-6.

\section{Influence of IL-6 on Adenosine $A_{1}$ Receptor Actions Upon Excitoxicity}

IL-6 increases the function and neuroprotective properties of postsynaptic adenosine $A_{1}$ receptors against glutamateinduced neurotoxicity. It is well known that the excessive activation of postsynaptic glutamate receptors by high concentrations of glutamate induces neuronal death in cultured cells. Interestingly, IL-6 was reported to minimize the consequences of high-glutamate levels by promoting neuronal rescue (Ali et al, 2000). To investigate a possible postsynaptic locus of IL-6-induced upregulation of $A_{1}$ receptors, we tested whether those neuroprotective actions of IL- 6 could be related to the amplification of $A_{1}$ receptors function. To minimize the number of killed animals, we cultured cortical neurons, which also abundantly express $A_{1}$ receptors. The rapid induction of neuronal adenosine $A_{1}$ receptor mRNA and protein by IL-6 (1-24h) was also observed in these neurons through reverse transcription (RT)-PCR experiments (Figure 4a) and quantitative analysis of four independent western blot experiments, respectively (Figure 4a).

In our conditions, glutamate-dependent neurotoxicity was completely abolished by MK801 treatment and therefore due to NMDA receptor stimulation (data not shown). We first compared the effect of various concentrations of glutamate $(10 \mu \mathrm{M}$ up to $300 \mu \mathrm{M})$ on the survival of cultured neurons kept in the absence or in the presence of IL- 6 . We found that treatment with IL-6 $(10 \mathrm{U} / \mathrm{ml})$ significantly increased neuronal rescue in comparison to control at all concentrations confirming earlier findings (Ali et al, 2000) whereas heat-inactivated IL-6 did not have any effect on neuronal survival (data not shown). In subsequent experiments adenosine $A_{1}$ receptor activity was blocked by a 15 min preincubation with DPCPX $(100 \mathrm{nM})$. The blockade of adenosine $A_{1}$ receptor activity had no influence on glutamate-induced neuronal death but completely abolished the protective effect of IL- 6 treatment as exemplified for 50, 25 , and $10 \mu \mathrm{M}$ glutamate (Figure $4 \mathrm{~b}$ ). On the other hand a 


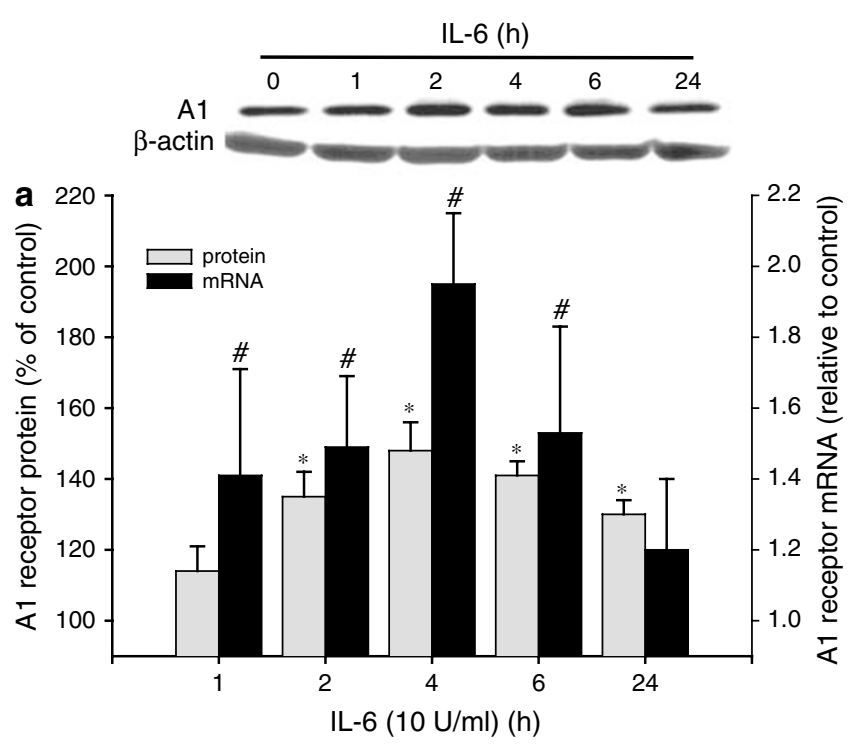

b
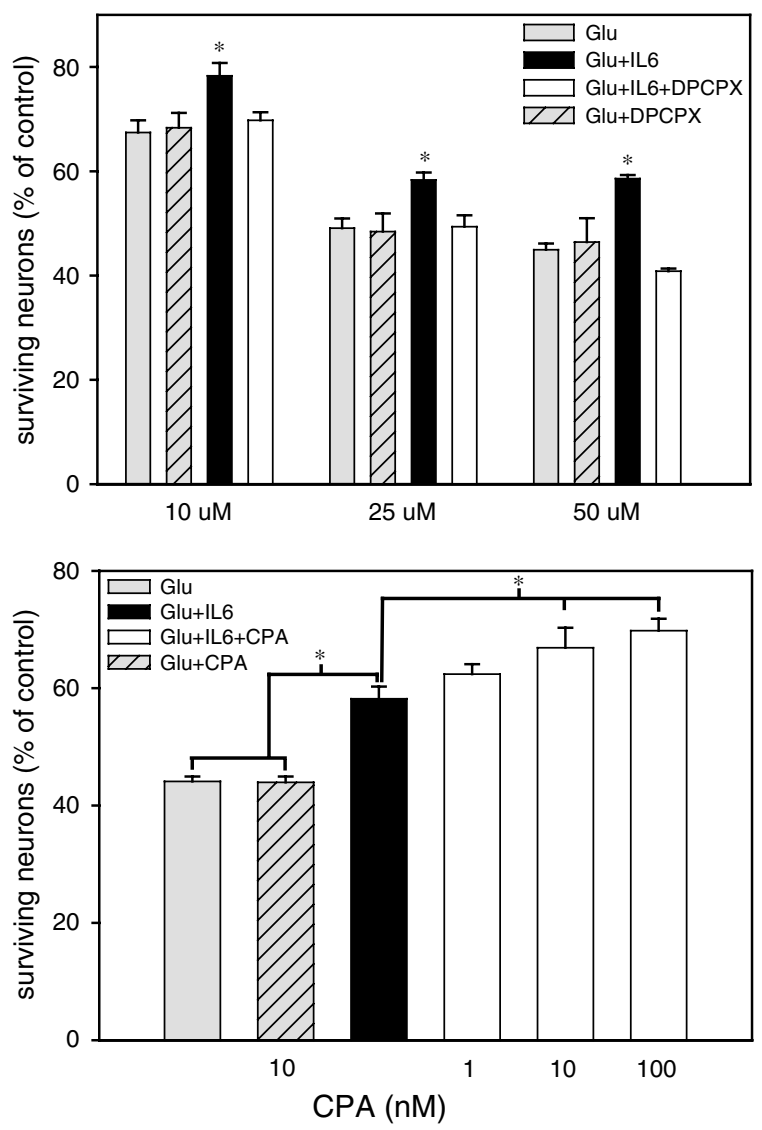

further stimulation ( $15 \mathrm{~min}$ before glutamate treatment) of adenosine $A_{1}$ receptors by various concentrations (1, 10, and $100 \mathrm{nM}$ ) of CPA significantly increased the neuronal survival after glutamate treatment $(50 \mu \mathrm{M})$ (Figure $4 \mathrm{c})$. As shown in Figure 4c CPA treatment (exemplified by $10 \mathrm{nM}$ ) without IL-6 preincubation did not significantly protect neurons against $50 \mu \mathrm{M}$ glutamate $(42 \pm 7 \%$ surviving neurons for glutamate per se and $46 \pm 7,44 \pm 8$, and $49 \pm 4 \%$ surviving neurons were found after $15 \mathrm{~min}$
Figure 4 Effects of interleukin-6 (IL-6) treatment on adenosine $A_{1}$ receptor expression and on excitotoxicity in primary cortical cultures. (a) Upregulation of adenosine $A_{\text {, receptor }}$ RNA and protein expression by $\mathrm{IL}-6$ treatment $(10 \mathrm{U} / \mathrm{ml})$ in cortical neurons. The inset in the figure shows a typical western blot experiment. (b) Pretreatment with IL-6 (I0 U/ml $24 \mathrm{~h})$ protected neurons from excitotoxicity induced by glutamate at various concentrations $(50 \mu \mathrm{M}, 25 \mu \mathrm{M}$, and $10 \mu \mathrm{M})$. Treatment with $100 \mathrm{nM}$ DPCPX ( $15 \mathrm{~min}$ before glutamate treatment) completely abolished the protective effect of IL-6 treatment but did not influence the effect of glutamate without IL-6 pretreatment. (c) Application of $\mathrm{N}^{6}$-cyclopentyladenosine (CPA, 15 min before glutamate treatment) at several concentrations $(\mathrm{I}, 10$, and $100 \mathrm{nM})$ significantly increased neuronal survival after glutamate treatment $(50 \mu \mathrm{M})$ only when neurons had been pretreated with IL-6. CPA (IO nM) without IL-6 did not affect glutamate-induced neurotoxicity. Data in (a) are given as mean \pm SEM from four independent western blot experiments and from three independent RT-PCR experiments. Data in (b) and (c) are given as mean \pm SEM $(n=3)$. The graphs represent typical experiments. Similar results have been obtained in five independent experiments. *Significantly different $(p<0.05)$.

pretreatment with 1,10 , and $100 \mathrm{nM}$ CPA, respectively). Data shown in Figure 4a-c concern a pool of experiments in which treatment with IL-6 was performed during $24 \mathrm{~h}$, but similar results were obtained when treatment with IL- 6 was performed during $6 \mathrm{~h}$ (data not shown).

\section{Influence of IL-6 on Adenosine $A_{1}$ Receptors In Vivo}

The next series of experiments were aimed to investigate the role of IL- 6 on the regulation of adenosine $A_{1}$ receptor expression in the brain in vivo. It is known that the expression of $A_{1}$ receptors in WT mice is increased after neuropathological events, such as seizures (Pagonopoulou et al, 1993; Vanore et al, 2001; Angelatou et al, 1991, 1993). On the other hand, several reports have shown that those noxious conditions trigger the release of IL-6 (Lehtimäki et al, 2003; Peltola et al, 1998, 2002). Accordingly, we used WT animals and IL-6-deficient mice to evaluate the relationship between the expression of IL- 6 and the upregulation of adenosine $A_{1}$ receptors in response to PTZ-induced seizures.

Differences in seizure scores between WT animals and IL6-deficient mice. As shown in Figure 5, seizure scores after a first PTZ injection did not differ between WT and IL-6deficient mice. However, whereas no change in seizure scores were observed in WT mice after a second PTZ injection round, IL-6-deficient mice displayed significant higher seizures $(p=0.03)$ on the second day (Figure 5). Moreover, none of the WT mice died after PTZ injections, whereas two of the IL-6-deficient mice did not survive the second application of PTZ.

Adenosine $A_{1}$ receptor $m R N A$ expression is downregulated after seizures in IL-6-deficient mice. Q-PCR analysis was carried out to investigate possible effects of seizure activity on $A_{1}$ receptor mRNA expression in IL-6-deficient mice and WT animals. No differences were observed in mice with lower seizure scores compared to control mice (data not shown). Similarly, no change in $A_{1}$ receptor expression was measured in WT animals with high seizures scores (Figure 6a). In contrast a significant $(p=0.03)$ 


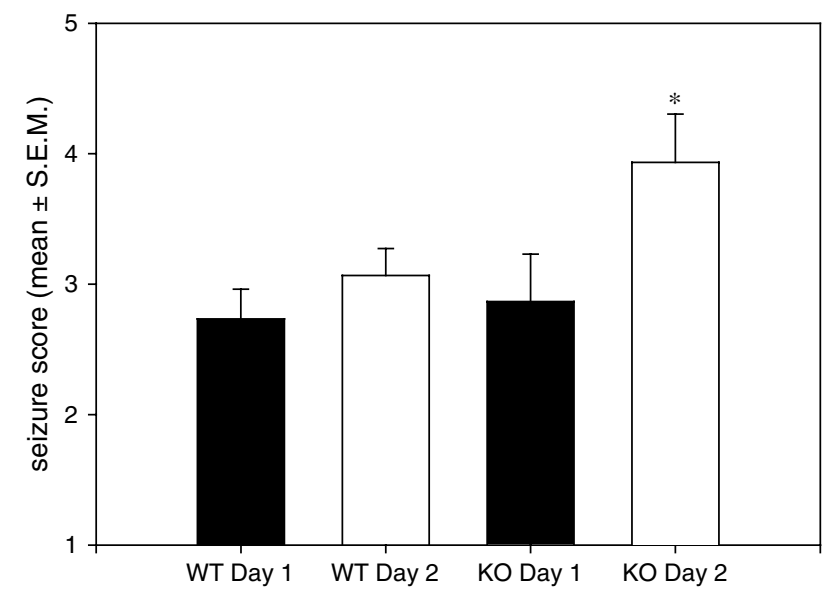

Figure 5 Differences in seizure scores between wild-type (WT) and IL6-deficient mice. There was no difference in seizure scores between WT and IL-6-deficient mice after the first PTZ injection, both mouse strains displayed mean seizure scores around 3. Similar seizure scores were also detected in WT mice after the second PTZ injection round, whereas IL-6deficient mice displayed significant higher seizures on the second day. *Significantly different $(p<0.05)$

downregulation of adenosine $A_{1}$ receptor mRNA expression was detected in IL-6-deficient mice with high seizure scores compared to controls (Figure 6a).

Seizure-induced upregulation of brain adenosine $A_{1}$ receptor expression depends on IL-6. Radioligand binding experiments using $\left[{ }^{3} \mathrm{H}\right]$-DPCPX have been performed to investigate the expression of adenosine $A_{1}$ receptors in the brain. The mice that received PTZ injections were divided in two groups according to the severity of the seizures in 'PTZlow score' and 'PTZ-high score' groups as described in 'Materials and Methods'. No difference was obtained between control and PTZ-low score WT animals. An increase in $\left[{ }^{3} \mathrm{H}\right]$-DPCPX binding was observed in WT of the PTZ-high score group, but this difference just failed to reach significance $(p$-value $=0.063)$. PTZ injections did not influence $\left[{ }^{3} \mathrm{H}\right]$-DPCPX binding in IL-6-deficient mice (Figure 6b). The failure to reach significance in WT animals most likely is due to the fact that a prominent seizuredependent induction of adenosine $\mathrm{A}_{1}$ receptor does not occur in all brain regions (Pagonopoulou et al, 1993; Vanore et al, 2001; Angelatou et al, 1993). It was therefore further decided to investigate the seizure effects in autoradiographic experiments that allowed the precise analysis of adenosine $A_{1}$ receptor expression in defined brain regions.

Adenosine $A_{1}$ receptor expression in animals with high seizure scores was further determined in hippocampus (CA1, CA2, CA3, and dentate gyrus) and cortex (entorhinal cortex), brain areas with high density of adenosine $A_{1}$ receptors and in which a prominent induction of receptor expression was reported after PTZ-induced seizures (Pagonopoulou et al, 1993; Vanore et al, 2001; Angelatou et al, 1993). A significant seizure-dependent induction of adenosine $A_{1}$ receptor expression was observed in all these brain areas that resembled earlier findings (Pagonopoulou et al, 1993) (Figure $7 \mathrm{a}$ exemplified for $\mathrm{CA} 1$ and cortex), whereas no
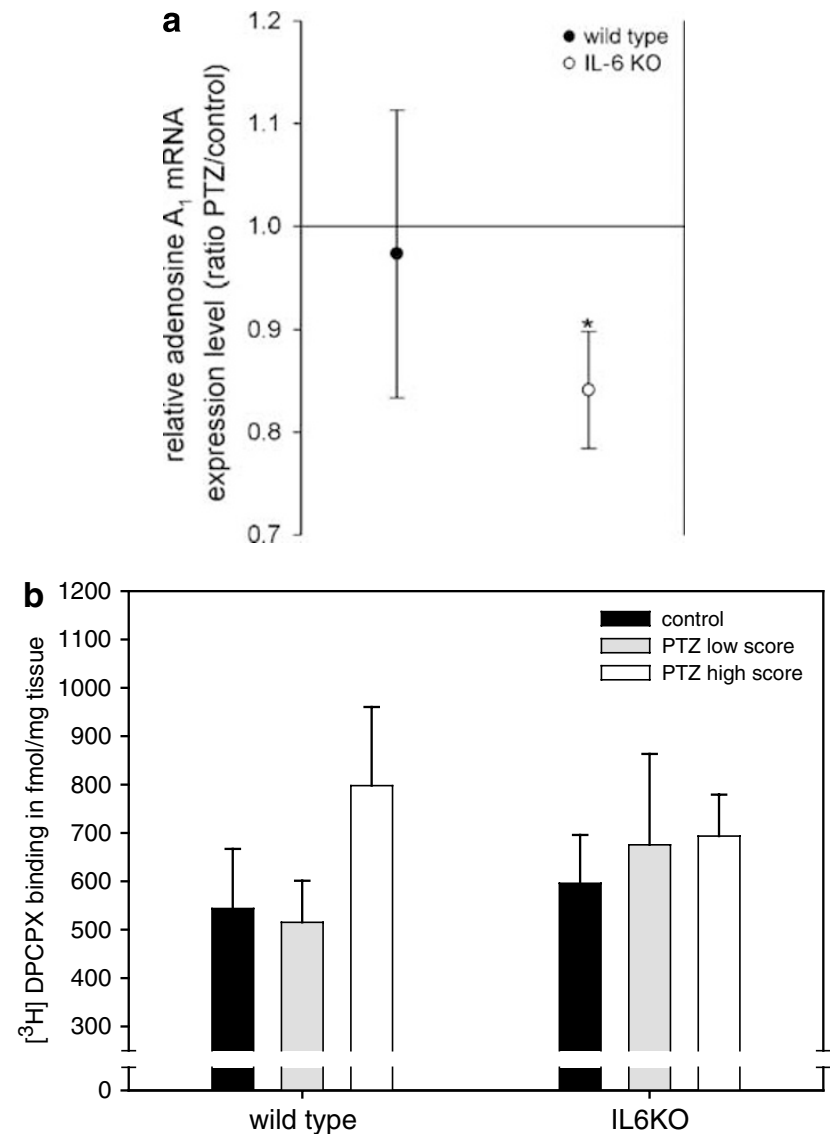

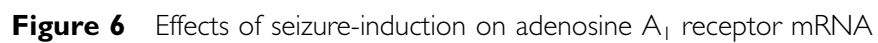
and protein expression in brain. (a) Real-time PCR analysis of adenosine $A_{1}$ receptor mRNA level in brains of wild-type (WT) and interleukin-6 (IL-6) knockout (KO) mice (normalized to rpl32A and HPRTI). Graph shows the relative expression level of mRNA in pentylenetetrazole (PTZ)-injected animals ('PTZ-high score') compared to controls. The expression level of controls is set to I. *Significant reduction of mRNA expression compared to controls $(p<0.05)$, determined by $t$-test. (b) Specific radioligand $\left[{ }^{3} \mathrm{H}\right]$ 1,3-dipropyl-8-cyclopentylxanthine (DPCPX) binding to adenosine $A_{1}$ receptors in brain membranes of WT and IL-6 KO mice with and without PTZ injection. The observed induction of adenosine $A_{\text {I }}$ receptor expression in WT animals just failed to reach significance $(p=0.063$ as determined by one-way ANOVA). Results are given as mean $\pm \operatorname{SEM}(n=5$, for mRNA expression; $n=3$ for radioligand binding).

effect was observed in IL-6-deficient animals. Pooling together the relative changes obtained in all brain areas seizures significantly $(p=0.02)$ increased the $A_{1}$ receptor expression in WT animals by $28 \pm 8 \%$ as compared to the basal situation. IL-6-deficient mice displayed significant $(p=0.02)$ lower expression of adenosine $A_{1}$ receptors ( $85 \pm 2 \%$ without seizure) when compared to WT controls and seizures did not change the expression of adenosine $A_{1}$ receptors in these animals ( $80 \pm 3 \%$ with seizures).

To investigate whether the seizure score after the first PTZ injection correlated with the upregulation of adenosine $A_{1}$ receptors we plotted day 1 seizure scores of PTZ-injected animals against the $\left[^{3} \mathrm{H}\right] \mathrm{CHA}$-binding results of the autoradiography experiments of individual animals (control and PTZ-injected animals). Statistical analysis revealed that the Pearson's correlation coefficient was significant in all hippocampal areas (exemplified for CA1, $p=0.003$ ) 
(Figure 7b) and cortex $p=0.0019$ (data not shown), indicating a positive correlation between seizure scores observed on day 1 and adenosine $A_{1}$ receptor expression in $\mathrm{WT}$ animals.

\section{DISCUSSION}

In the present work we identified IL-6 as an important factor for regulating the expression of functional hippocampal and cortical adenosine $A_{1}$ receptors, thereby providing enhanced protection against noxious conditions both in vitro and in vivo. In our conditions, the exposure to IL-6 significantly enhanced the ability of adenosine $A_{1}$ receptors to inhibit excitatory synaptic transmission in acute hippocampal slices, an effect that was particularly evident during hypoxic insults. Since the efficient inhibition of synaptic transmission by adenosine during hypoxia facilitates the subsequent recovery to basal conditions (Sebastião et al, 2001), it is likely that the amplification of $\mathrm{A}_{1}$ receptor-mediated function by IL- 6 minimizes the consequences of a hypoxic period in the brain. Our data furthermore show that IL-6-induced enhancement of $A_{1}$ receptor expression has a great relevance to the survival of endangered neurons exposed to high concentrations of glutamate. However, the mechanisms by which IL-6 potentiates $A_{1}$ receptor function on synaptic transmission an on neuronal survival might not necessarily be connected. While the prevention of glutamate-induced neuronal death probably occurs at the postsynaptic or somatic level, the enhanced inhibition of synaptic transmission is mostly a presynaptic phenomenon. In vivo experiments furthermore suggested a crucial role for IL-6 in regulating the expression of adenosine $A_{1}$ receptor in the brain. Using autoradiography we observed a significant increase of adenosine $A_{1}$ receptor expression in the hippocampus and cortex in WT animals after PTZ-induced seizures, as it was already described by others (Pagonopoulou et al, 1993; Vanore et al, 2001; Angelatou et al, 1991). A remarkable novelty in the present work was that the PTZ-induced increased of adenosine $A_{1}$ receptor expression was completely lacking in the brains of IL-6-deficient mice. It was previously suggested that the upregulation of adenosine $A_{1}$ receptor expression occurring in response to seizures would protect neurons against subsequent convulsive episodes (Vanore et al, 2001, Gouder et al, 2003). Our data corroborates that hypothesis, since animals that failed to increase the expression of adenosine $A_{1}$ receptors in the brain (IL-6-deficient mice) experienced higher seizure scores after the second injection of PTZ and, in some cases, even death. Interestingly, the lack of adenosine $A_{1}$ receptor upregulation was observed in cortex and hippocampus of IL-6-deficient mice, indicating that with respect to the relationship between IL- 6 and adenosine $A_{1}$ receptor expression, both brain regions behaved similar. This in vivo observation is corroborated by our in vitro findings, since IL-6 also increased neuronal adenosine $A_{1}$ receptor expression and function in hippocampal slices and in cortical neurons.

We previously showed that IL- 6 induces the expression of adenosine $A_{1}$ receptors in glia cells (Biber et al, 2001), where even modest changes in $A_{1}$ receptor expression cause marked changes in adenosine $A_{1}$ receptor-meditated
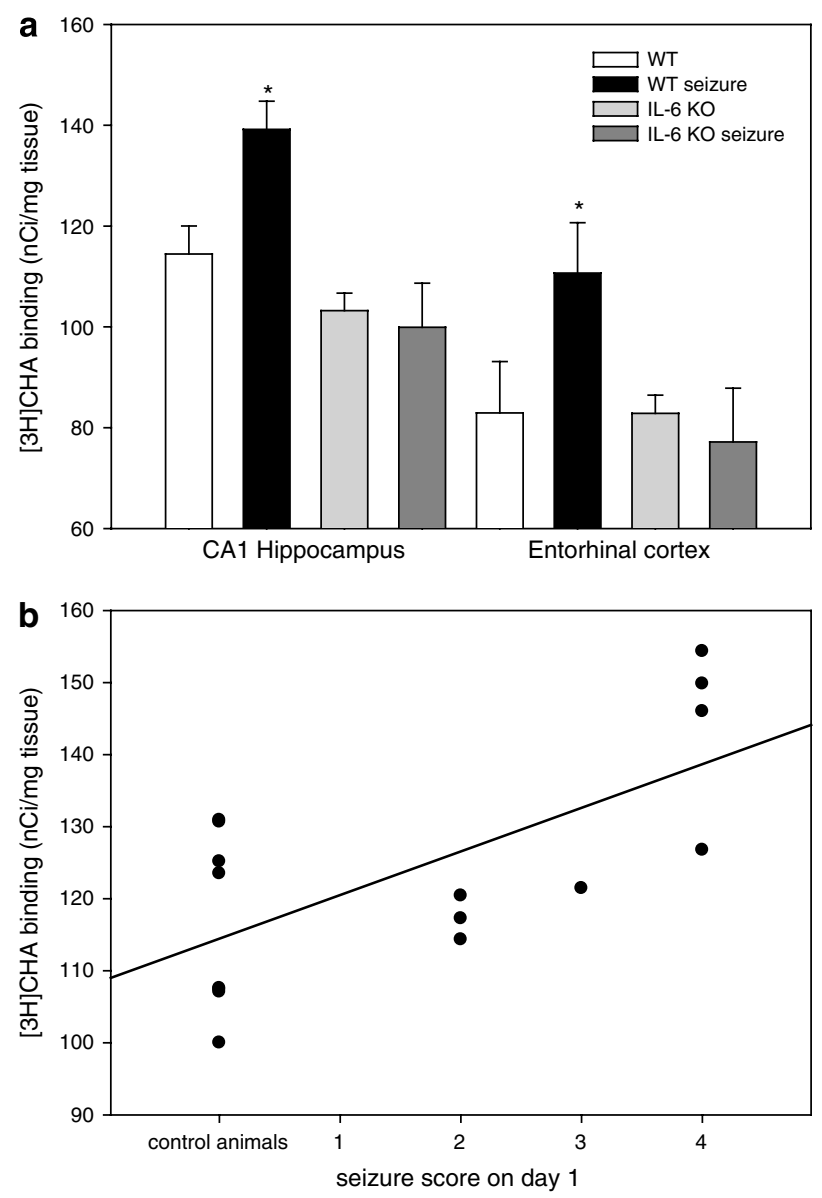

Figure 7 Autoradiographic analysis of adenosine $A_{1}$ receptor expression in hippocampus and cortex of wild-type (WT) and interleukin-6 (IL-6)deficient mice. Adenosine $A_{1}$ receptor expression was determined in hippocampus (CAI) and cortex (entorhinal cortex). (a) Note that seizures significantly induced the $A_{1}$ receptor expression compared to the basal situation. Untreated IL-6-deficient mice (IL-6 KO) displayed lower

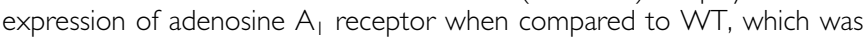
unaffected by the induction of seizures (IL-6 KO seizures). (b) Adenosine $A$, receptor expression in WT mice is correlated to seizure scores after the first PTZ injection. Correlation analysis of adenosine $A_{1}$ receptor expression and seizure scores were carried out by plotting the expression data against the seizure scores compared to untreated control animals. Each data point in the graphs represents an individual animal (seven control animals; 3, I, and 4 animals with seizure scores 2, 3, and 4, respectively). Positive correlations were found between adenosine $A_{1}$ receptor expression in hippocampus (b) and seizure scores induced by the first PTZ injection in WT animals. Data in (a) are represented as mean \pm SEM per group (4-8 animals per group). *Significantly different from untreated controls; $p<0.05$ by one-way ANOVA. Statistical analysis revealed a significant Pearson's correlation coefficient of $p=0.003$ for hippocampus (b)

signaling (Biber et al, 1997). Now, we extended these findings to neurons, the brain cells where the predominant expression of adenosine $A_{1}$ receptors occurs (Onodera and Kogure, 1988; Ulas et al, 1993; Swanson et al, 1995) and where adenosine acts to refrain excitatory transmission and to protect from uncoordinated firing (Dragunow, 1988; Dunwiddie and Masino, 2001). Indeed, the neuronal adenosine $A_{1}$ receptor represents a major endogenous neuroprotective system and it has long been suggested that the upregulation of $A_{1}$ receptor expression increases its 
neuroprotective capacities (for review, see Rudolphi and Schubert, 1996; Dunwiddie and Masino, 2001). Accordingly, upregulation of adenosine $A_{1}$ receptor expression has been observed in mice and rats after chemically induced seizures and in post-mortem tissue of humans suffering from epilepsy (Pagonopoulou et al, 1993; Vanore et al, 2001; Angelatou et al, 1991). An upregulation of adenosine $A_{1}$ receptors in the presence of extracellular adenosine at high concentrations (as it occurs during seizures) seems a rather unusual feature, since adenosine $\mathrm{A}_{1}$ receptors are normally desensitized in the presence of high concentrations of adenosine or after a prolonged exposure to selective agonists (Abbracchio et al, 1992; Ruiz et al, 1996; Hettinger et al, 1998; Latini and Pedata, 2001). The data presented here might provide an explanation for this paradoxical situation, since IL-6-induced synthesis of $A_{1}$ receptors could counteract or overrule $A_{1}$ receptor desensitization caused by prolonged exposure to high levels of adenosine released during seizures.

Our data showing that IL-6-deficient mice have increased susceptibility to PTZ-induced seizures are in accordance with two recent studies (de Luca et al, 2004; de Sarro et al, 2004), which showed that seizures in IL-6-deficient mice could be induced by much lower doses of several substances. By analyzing the effects of these different substances, the authors (de Sarro et al, 2004) concluded that IL-6 knockout mice might have impaired GABA inhibitory inputs and enhanced neurotransmission through glutamate receptors. In light of the present results, this enhancement of excitatory transmission is probably due to a reduced expression of adenosine $A_{1}$ receptors in the brain of IL-6-deficient mice. IL-6-dependent increase in neuronal $A_{1}$ receptor function might also underlie IL-6-induced inhibition of glutamate release and neuronal excitability in rat cortex (D'Arcangelo et al, 2000).

Inhibition of the expression of inflammatory genes in brain significantly aggravates the severity of PTZ-induced seizures (Asanuma et al, 1995). It is noteworthy that such inhibition only affected seizures after the second PTZ injection, similarly to what we observed in IL-6-deficient mice. Asanuma et al (1995) concluded that neuroinflammation occurring in response to the first seizures would initiate processes that protect the brain from upcoming seizure events. We now advanced a step in this hypothesis, showing that inflammatory events (release of IL-6) upregulate the expression and function of protective adenosine $A_{1}$ receptors.

A reduced inflammatory reaction in conjunction with an increase in mortality of IL-6-deficient mice after seizure induction was described by Penkowa et al (2001). Two of our IL-6-deficient mice (but none of the controls) also died as consequence of the second PTZ induction. Therefore, although IL-6 might have modest neuroprotective effects in vitro (present study, Ali et al, 2000; Pizzi et al, 2004) its function in vivo can be crucial for animal survival. Since an increased expression of IL-6 (see below) and of adenosine $\mathrm{A}_{1}$ receptors also occurs in humans (Angelatou et al, 1993), it is likely that rapid IL-6 release in response to seizures is protective in upcoming seizure events by upregulating neuronal adenosine $A_{1}$ receptors. This might be different when IL- 6 is chronically elevated. Increased neuronal death has been described after chronic treatment with IL-6 in vitro

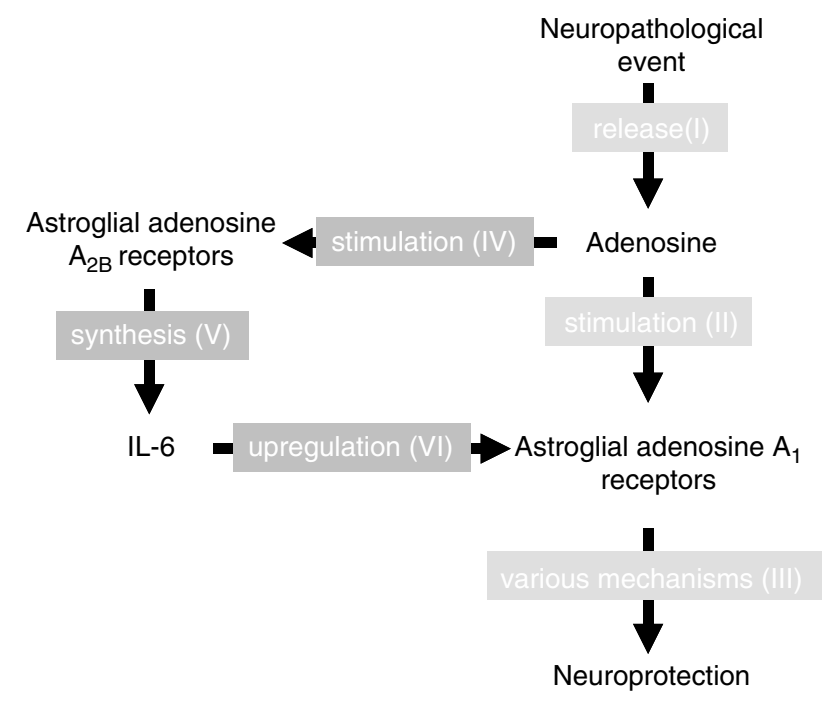

Figure 8 Scheme that illustrates the proposed relationship between interleukin-6 (IL-6) and the adenosinergic system in neuroprotection. (I-III) Classical pathway in adenosine $A_{1}$ receptor-mediated neuroprotection. Any neuropathological condition induces the release of adenosine (I) that stimulates neuronal adenosine $A$, receptors (II) and causes neuroprotection by membrane hyperpolarization and inhibition of neurotransmitter release (III). (IV-VI) Adenosine at high concentration is sufficient enough to stimulate low-affinity adenosine $A_{2 B}$ receptors in astrocytes (IV) that induce the synthesis of IL-6 in these cells $(V)$. IL-6 upregulates the expression of neuronal adenosine $A_{1}$ receptors $(\mathrm{VI})$ and thus guarantees the presence of protective receptors that without IL-6 would undergo desensitization due to high ligand concentrations.

and animals with chronic IL-6 expression in astrocytes show enhanced neurodegeneration and increased sensitivity to kainite-induced seizures (Qiu et al, 1998; Nelson et al, 2004; Conroy et al, 2004; Campbell et al, 1993; Samland et $a l, 2003)$. It is not yet clear whether adenosine $A_{1}$ receptor expression is affected by chronic elevated IL-6 levels. Experiments to address this question are currently underway in our laboratory.

Rapid induction of IL- 6 expression in the brain is known to occur in most (if not all) neuropathological conditions, including seizures in humans (Lehtimäki et al, 2003, 2004; Peltola et al, 1998, 2002; Jankowsky and Patterson, 1999) where IL-6 levels in the cerebrospinal fluid up to $100 \mathrm{pg} / \mathrm{ml}$ have been found (Peltola et al, 2000). Astrocytes are a major source of IL-6 in the brain (van Wagoner and Benveniste, 1999). We and others have shown that activation of adenosine $\mathrm{A}_{2 \mathrm{~B}}$ receptors in astrocytes leads to the synthesis and release of IL-6 (Fiebich et al, 1996; Schwaninger et al, 1997, 2000). Since adenosine $\mathrm{A}_{2 \mathrm{~B}}$ receptors have a low affinity for adenosine, high concentrations of the ligand (which are found during seizures or hypoxia) are required to activate this receptor. Thus, we propose that the following series of events are involved in the cross talk between IL-6 and the adenosinergic system during neuropathological conditions: (1) readily released adenosine activates low-affinity adenosine $A_{2 B}$ receptors in astrocytes that in response (2) secrete IL-6, which in turn (3) increases the expression adenosine $A_{1}$ receptors, and consequently (4) amplifies their neuroprotective properties (Figure 8).

According to the above-mentioned assumptions, high levels of extracellular adenosine are required to initiate the 
process. It is worth to note that a significant correlation was found between the seizure scores in the first day and the induction of adenosine $A_{1}$ receptor expression in the hippocampus and cortex of WT mice, suggesting that only in animals with high-seizure scores a sufficient amount of adenosine was released to stimulate the synthesis of IL-6. Thus, the feed-forward loop now proposed (Figure 8) leading to amplification of adenosine $A_{1}$ receptor signaling might be particularly relevant in vivo to counteract pathological conditions associated with intense neuronal firing.

In conclusion, the data presented here demonstrate that IL-6 induces the expression of neuronal adenosine $A_{1}$ receptors in vitro and in vivo. This mechanism results in improved adenosinergic signaling and increased neuronal survival, and thus constitutes a molecular foundation of IL-6-induced neuromodulation and neuroprotection.

\section{ACKNOWLEDGEMENTS}

Work in Lisbon was supported by Fundação para a Ciência e Tecnologia (FCT). CC Fernandes and A Pinto-Duarte are in receipt of FCT fellowships (SFRH/BD/18046/2004/ and SFRH/BD/21589/2005). Work of K Biber and MC Wittendorp was supported by school of Behavioral Cognitive Neurosciences (BCN, Groningen). We greatly acknowledge the gift of anti-adenosine $A_{1}$ receptor antibody by Dr Rafael Franco and support for western blot experiments by $\mathrm{MJ}$ Diógenes and the group of Dr João Barata at the IMM. We thank Prof B Hamprecht and Dr Alexandre de Mendonça for critical reading of the manuscript and valuable comments.

\section{DISCLOSURE/CONFLICT OF INTEREST}

The authors declare that they have no competing financial interests.

\section{REFERENCES}

Abbracchio MP, Fogliatto G, Paoletti AM, Rovati GE, Cattabeni F (1992). Prolonged in vitro exposure of rat brain slices to adenosine analogues: selective desensitization of adenosine $A_{1}$ but not $\mathrm{A}_{2}$ receptors. Eur J Pharmacol 227: 317-324.

Ali C, Nicole O, Docagne F, Lesne S, MacKenzie ET, Nouvelot A et al (2000). Ischemia-induced interleukin-6 as a potential endogenous neuroprotective cytokine against NMDA receptormediated excitotoxicity in the brain. J Cereb Blood Flow Metab 20: 956-966.

Anderson WW, Collingridge GL (2001). The LTP program: a data acquisition program for on-line analysis of long-term potentiation and other synaptic events. J Neurosci Methods 108: 71-83.

Anderson WW, Collingridge GL (2007). Capabilities of the WinLTP data acquisition program extending beyond basic LTP experimental functions. J Neurosci Methods 162: 346-356.

Angelatou F, Pagonopoulou O, Kostopoulos G (1991). Changes in seizure latency correlate with alterations in $\mathrm{A}_{1}$ adenosine receptor binding during daily repeated pentylentetrazol-induced convulsions in different mouse brain areas. Neurosci Lett 132: 203-206.

Angelatou F, Pagonopoulou O, Maraziotis T, Olivier A, Villemeure JG, Avoli $M$ et al (1993). Upregulation of $A_{1}$ adenosine receptors in human temporal lobe epilepsy: a quantitative autoradiographic study. Neurosci Lett 163: 11-14.

Arrigoni E, Crocker AJ, Saper CB, Greene RW, Scammell TE (2005). Deletion of presynaptic adenosine A1 receptors impairs the recovery of synaptic transmission after hypoxia. Neuroscience 132: $575-580$

Asanuma M, Ogawa N, Nishibayashi S, Kondo Y, Mori A (1995). Effects of repeated injection of cyclosporin A on pentylenetetrazol-induced convulsion and cyclophilin mRNA levels in rat brain. Neurochem Res 20: 101-105.

Barrie AP, Nicholls DG (1993). Adenosine A receptor inhibition of glutamate exocytosis and protein kinase $\mathrm{C}$-mediated decoupling. J Neurochem 60: 1081-1086.

Bensadoun JC, Pereira de Almeida L, Dréano M, Aebischer P, Déglon N (2001). Neuroprotective effect of interleukin-6 and IL6/IL6R chimera in the quinolinic acid rat model of Huntington's syndrome. Eur J Neurosci 14: 1753-1761.

Biber K, Klotz K-N, Berger M, Gebicke-Haerter PJ, van Calker D (1997). Adenosine $A_{1}$ receptor-mediated activation of phospholipase $\mathrm{C}$ in cultured astrocytes depends on the level of receptor expression. J Neurosci 17: 4956-4964.

Biber K, Lubrich B, Fiebich BL, Boddeke HW, van Calker D (2001). Interleukin- 6 enhances expression of adenosine $A(1)$ receptor mRNA and signaling in cultured rat cortical astrocytes and brain slices. Neuropsychopharmacology 24: 86-96.

Bolin LM, Strycharska-Orczyk I, Murray R, Langston JW, Di Monte D (2002). Increases vulnerability of dopaminergic neurons in MPTP-lesioned interleukin-6 deficient mice. J Neurochem 83: 167-175.

Campbell IL, Abraham CR, Masliah E, Kemper P, Inglis JD, Oldstone MBA et al (1993). Neurologic diseases induced in transgenic mice by cerebral overexpression of interleukin 6. Proc Natl Acad Sci 90: 10061-10065.

Carlson NG, Wieggel WA, Chen J, Bacchi A, Rogers SW, Gahring LC (1999). Inflammatory cytokines IL- $1 \alpha$, IL- $1 \beta$, Il-6, and TNF- $\alpha$ impart neuroprotection to an excitotoxin through distinct pathways. J Immunol 163: 3963-3968.

Chomczynski P, Sacchi N (1987). Single-step method of RNA isolation by acid guanidinium thiocyanate-phenol-chloroform extraction. Anal Biochem 162: 156-159.

Citri A, Malenka RC (2007). Synaptic plasticity: multiple forms, functions, and mechanisms. Neuropsychopharmacology, advance online publication, August 29, 2007 (DOI 10.1038/sj.npp. 1301559).

Conroy SM, Nguyen V, Quina LA, Blakely-Gonzales P, Ur C, Netzeband JG et al (2004). Interleukin-6 produces neuronal loss in developing cerebellar granule neuron cultures. J Neuroimmunol 155: 43-54.

Dalpiaz A, Manfredini S (2002). Adenosine $A_{1}$ receptor: analysis of the potential therapeutic effects obtained by its activation in the central nervous system. Curr Med Chem 9: 1923-1937.

d'Arcangelo G, Tancredi V, Onofri F, D Antuono M, Giovedi S, Benfenati F (2000). Interleukin-6 inhibits neurotransmitter release and the spread of excitation in the rat cerebral cortex. Eur J Neurosci 12: 1241-1252.

de Jong EK, Dijkstra IM, Hensens M, Brouwer N, van Amerongen M, Liem RSB et al (2005). Vesicle-mediated transport and release of CCL21 in endangered neurons: a possible explanation for microglia activation remote from a primary lesion. J Neurosci 25: 7548-7557.

de Luca G, Di Giorgio R M, Macaione S, Calpona PR, Costantino S, Di Paola ED et al (2004). Susceptibility to audiogenic seizure and neurotransmitter amino acid levels in different brain areas of IL-6-deficient mice. Pharmacol Biochem Behav 78: 75-81.

de Sarro G, Russo E, Ferreri G, Giuseppe B, Flocco MA, Di Paola E $\mathrm{D}$ et al (2004). Seizure susceptibility to various convulsant stimuli of knockout interleukin-6 mice. Pharmacol Biochem Behav 77: 761-766. 
de Mendonca A, Sebastiao AM, Ribeiro JA (1995). Inhibition of NMDA receptor-mediated currents in isolated rat hippocampal neurones by adenosine $A_{1}$ receptor activation. Neuroreport 6: 1097-1100.

Diógenes MJ, Fernandes CC, Sebastião A, Ribeiro JA (2004). Activation of adenosine $A_{2 A}$ receptor facilitates brain-derived neurotrophic factor modulation of synaptic transmission in hippocampal slices. J Neurosci 24: 2905-2913.

Dragunow M (1988). Purinergic mechanisms in epilepsy. Prog Neurobiol 31: 85-108.

Dunwiddie TV, Masino SA (2001). The role and regulation of adenosine in the central nervous system. Annu Rev Neurosci 24: 31-55.

Fiebich BL, Biber K, Gyufko K, Berger M, Bauer J, van Calker D (1996). Adenosine $A_{2 B}$ receptors mediate an increase in interleukin (IL)- 6 mRNA and IL-6 protein synthesis in human astroglioma cells. J Neurochem 66: 1426-1431.

Gadient RA, Otten UH (1997). Interleukin-6 (IL-6)-a molecule with both beneficial and destructive potentials. Prog Neurobiol 52: 379-390.

Gerber U, Gahwiler BH (1994). GABAb and adenosine receptors mediate enhancement of the $\mathrm{K}+$ current, IAHP, by reducing adenylyl cyclase activity in rat CA3 hippocampal neurons. J Neurophysiol 72: 2360-2367.

Gouder N, Fritschy JM, Boison D (2003). Seizure suppression by adenosine $A_{1}$ receptor activation in a mouse model of pharmacoresistant epilepsy. Epilepsia 44: 877-885.

Gruol DL, Nelson TE (1997). Physiological and pathological roles of interleukin-6 in the central nervous system. Mol Neurobiol 15: 307-339.

Herrmann O, Tarabin V, Suzuki S, Attigah N, Coserea I, Schneider A et al (2003). Regulation of body temperature and neuroprotection by endogenous interleukin- 6 in cerebral ischemia. J Cereb Blood Flow and Metab 23: 406-415.

Hettinger BD, Leid M, Murray T F (1998). Cyclopentyladenosineinduced homologous down-regulation of $\mathrm{A}_{1}$ adenosine receptors $\left(A_{1} A R\right)$ in intact neurons is accompanied by receptor sequestration but not a reduction in $A_{1} A R$ mRNA expression or $G$ protein alpha-subunit content. J Neurochem 71: 221-230.

Jankowsky JL, Patterson PH (1999). Differential regulation of cytokine expression following pilocarpine-induced seizure. Exp Neurol 159: 333-346.

Kondziella D, Bidar A, Urfjell B, Sletvold O, Sonnewald U (2002). The pentylenetetrazole-kindling model of epilepsy in SAMP8 mice: behavior and metabolism. Neurochem Int 40: 413-418.

Lambert NA, Teyler TJ (1991). Adenosine depresses excitatory but not fast inhibitory synaptic transmission in area CA1 of the rat hippocampus. Neurosci Lett 122: 50-52.

Latini S, Pedata F (2001). Adenosine in the central nervous system: release mechanisms and extracellular concentrations. J Neurochem 79: 463-484.

Lehtimäki KA, Peltola J, Koskikallio E, Keranen T, Honkaniemi J (2003). Expression of cytokines and cytokine receptors in the rat brain after kainic acid-induced seizures. Brain Res Mol Brain Res 110: 253-260.

Lehtimäki KA, Keränen T, Huhtala H, Hurme M, Ollikainen J, Honkaniemi J et al (2004). Regulation of Il-6 system in cerebrospinal fluid and serum compartments by seizures: the effect of seizure type and duration. J Neuroimmunol 152: 121-125.

Livak KJ, Schmittgen TD (2001). Analysis of relative gene expression data using real-time quantitative PCR and the 2(-delta delta C(T)). Method Methods 25: 402-408.

Lucchi R, Latini S, de Mendonça A, Sebastião AM, Ribeiro JA (1996). Adenosine by activating $A_{1}$ receptors prevents $G_{A B A} A^{-}$ mediated actions during hypoxia in the rat hippocampus. Brain Res 732: 261-266.
Loddick SA, Turnbull AV, Rothwell NJ (1998). Cerebral interleukin-6 is neuroprotective during permanent focal cerebral ischemia in the rat. J Cereb Blood Flow Metab 18: 176-179.

Lohse MJ, Lenschow V, Schwabe U (1984). Interaction of barbiturates with adenosine receptors in rat brain. Naunyn Schmiedebergs Arch Pharmacol 326: 69-74.

Marchetti L, Klein M, Schlett K, Pfizenmaier K, Eisel UL (2004). Tumor necrosis factor (TNF)-mediated neuroprotection against glutamate-induced excitotoxicity is enhanced by $N$-methyl-Daspartate receptor activation. Essential role of a TNF receptor 2-mediated phosphatidylinositol 3-kinase-dependent NF-kappa B pathway. J Biol Chem 279: 32869-32881.

Nelson TE, Netzeband JG, Gruol DL (2004). Chronic interleukin-6 exposure alters metabotropic glutamate receptor-activated calcium signalling in cerebellar Purkinje neurons. Eur J Neurosci 20: $2387-2400$.

Onodera H, Kogure K (1988). Differential localization of adenosine $\mathrm{A}_{1}$ receptors in the rat hippocampus: a quantitative autoradiographic study. Brain Res 458: 212-217.

Pagonopoulou O, Angelatou F, Kostopoulos G (1993). Effect of pentylentetrazol-induced seizures on $\mathrm{A}_{1}$ adenosine receptor regional density in the mouse brain: a quantitative autoradiographic study. Neuroscience 56: 711-716.

Peltola J, Hurme M, Miettinen A, Keranen T (1998). Elevated levels of interleukin-6 may occur in cerebrospinal fluid from patients with recent epileptic seizures. Epilepsy Res 31: 129-133.

Peltola J, Laaksonen J, Haapala AM, Hurme M, Rainesalo S, Keranen T (2002). Indicators of inflammation after recent tonicclonic epileptic seizures correlate with plasma interleukin-6 levels. Seizure 11: 44-46.

Peltola J, Palmio J, Korhonen L, Suhonen J, Miettinen A, Hurme M et al (2000). Interleukin-6 and interleukin-1 receptor antagonist in cerebrospinal fluid from patients with recent tonic-clonic seizures. Epilepsy Res 41: 205-211.

Penkowa M, Molinero A, Carrasco J, Hidalgo J (2001). Interleukin6 deficiency reduces the brain inflammatory response and increases oxidative stress and neurodegeneration after kainic acid-induced seizures. Neuroscience 102: 805-818.

Pinto-Duarte A, Coelho JE, Cunha RA, Ribeiro JA, Sebastiao AM (2005). Adenosine $A_{2 A}$ receptors control the extracellular levels of adenosine through modulation of nucleoside transporters activity in the rat hippocampus. $J$ Neurochem 93: 595-604.

Pizzi M, Sarnico I, Boroni F, Benarese M, Dreno M, Garotta G et al (2004). Prevention of neuron and oligodendroctye degeneration by interleukin-6 (IL-6) and IL-6 receptor/IL-6 fusion protein in organotypic hippocampal slices. Mol Cell Neurosci 25: 301-311.

Qiu Z, Sweeney DD, Netzeband JG, Gruol DL (1998). Chronic interleukin-6 alters NMDA receptor-mediated membrane responses and enhances neurotoxicity in developing CNS neurons. J Neurosci 18: 10445-10456.

Ribeiro JA (2005). What can adenosine neuromodulation do for neuroprotection? Curr Drug Targets CNS Neurol Disord 4: 325-329.

Rudolphi KA, Schubert P (1996). Purinergic interventions in traumatic and ischemic injury. In: Peterson PL, Willis PW (eds) Novel Thearapies for CNS Injuries. Boca Raton: New York, London, Tokyo: CRC Press Inc, pp 327-342.

Ruiz A, Sanz JM, Gonzalez-Calero G, Fernandez M, Andres A, Cubero A et al (1996). Desensitization and internalization of adenosine $A_{1}$ receptors in rat brain by in vivo treatment with $\mathrm{R}$ PIA: involvement of coated vesicles. Biochim Biophys Acta 1310: 168-174.

Samland H, Huitron-Resendiz S, Masliah E, Criado J, Hendriksen SJ, Campbell IL (2003). Profound increase in sensitivity to glutamatergic- but not to cholinergic agonist-induced seizures in transgenic mice with astrocyte production of IL-6. J Neurosci Res 73: 176-187. 
Schurr A, Reid KH, Tseng MT, West C, Rigor BM (1986). Adaptation of adult brain tissue to anoxia and hypoxia in vitro. Brain Res 374: 244-248.

Schwaninger M, Neher M, Viegas E, Schneider A, Spranger M (1997). Stimulation of interleukin-6 secretion and gene transcription in primary astrocytes by adenosine. J Neurochem 69: 1145-1150.

Schwaninger M, Petersen N, Prinz S, Sallmann S, Neher M, Spranger M (2000). Adenosine-induced expression of interleukin-6 in astrocytes through protein kinase A and NF-IL-6. Glia 31: $51-58$.

Sebastião AM, Cunha RA, de Mendonça A, Ribeiro JA (2000). Modification of adenosine modulation of synaptic transmission in the hippocampus of aged rats. Br J Pharmacol 131: 1629-1634.

Sebastião AM, de Mendonça A, Moreira T, Ribeiro JA (2001). Activation of synaptic NMDA receptors by action potentialdependent release of transmitter during hypoxia impairs recovery of synaptic transmission on reoxygenation. J Neurosci 21: 8564-8571.

Sebastião AM, Stone TW, Ribeiro JA (1990). The inhibitory adenosine receptor at the neuromuscular junction and hippocampus of the rat: antagonism by 1,3,8-substituted xanthines. Br J Pharmacol 101: 453-459.

Staff NP, Jung HY, Thiagarajan T, Yao M, Spruston N (2000). Resting and active properties of pyramidal neurons in subiculum and CA1 of rat hippocampus. J Neurophysiol 84: 2398-2408.

Stone TW (2002). Purines and neuroprotection. Adv Exp Med Biol 513: $249-280$.
Swanson TH, Drazba JA, Rivkees SA (1995). Adenosine $A_{1}$ receptors are located predominantly on axons in the rat hippocampal formation. J Comp Neurol 363: 517-531.

Swartz KR, Liu F, Sewell D, Schochet T, Campbell I, Sandor M et al (2001). Interleukin-6 promotes post-traumatic healing in the central nervous system. Brain Res 896: 86-95.

Trussell LO, Jackson MB (1985). Adenosine-activated potassium conductance in cultured striatal neurons. Proc Natl Acad Sci USA 82: $4857-4861$.

Ulas J, Brunner LC, Nguyen L, Cotman CW (1993). Reduced density of adenosine $A_{1}$ receptors and preserved coupling of adenosine $A_{1}$ receptors to $G$ proteins in Alzheimer hippocampus: a quantitative autoradiographic study. Neuroscience $\mathbf{5 2}$ 843-854.

Vanore G, Giraldez L, Rodriguez de Lores Arnaiz G, Girardi E (2001). Seizure activity produces differential changes in adenosine $A_{1}$ receptors within rat hippocampus. Neurochem Res 26: 225-230.

van Wagoner NJ, Benveniste EN (1999). Interleukin-6 expression and regulation in astrocytes. J Neuroimmunol 100: 124-139.

Wittendorp MC, van Frijtag Drabbe Kunzel J, Ijzerman AP, Boddeke HWGM, Biber K (2004). The mouse brain adenosine $A_{1}$ receptor: functional expression and pharmacology. Eur $J$ Pharmacol 487: 73-79.

Yan L, Burbiel JC, Maass A, Muller CE (2003). Adenosine receptor agonists: from basic medicinal chemistry to clinical development. Expert Opin Emerg Drugs 8: 537-576.

Yoon KW, Rothman SM (1991). Adenosine inhibits excitatory but not inhibitory synaptic transmission in the hippocampus. J Neurosci 11: 1375-1380. 